CRYSTALLOGRAPHIC COMMUNICATIONS

ISSN 2056-9890

Received 18 September 2019

Accepted 16 October 2019

Edited by A. J. Lough, University of Toronto, Canada

Keywords: crystal structure; 2-oxoquinoline; alkyne; weak intermolecular interactions; $\pi$ stacking; Hirshfeld surface.

CCDC reference: 1959642

Supporting information: this article has supporting information at journals.iucr.org/e

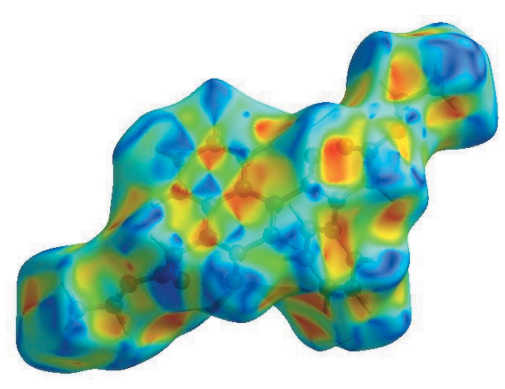

OPEN $\odot$ ACCESS

\section{Crystal structure, Hirshfeld surface analysis and DFT studies of ethyl 2-\{4-[(2-ethoxy-2-oxoethyl)- (phenyl)carbamoyl]-2-oxo-1,2-dihydroquinolin-1- yl\}acetate}

\author{
Yassir Filali Baba, ${ }^{\mathrm{a} *}$ Tuncer Hökelek, ${ }^{\mathrm{b}}$ Manpreet Kaur, ${ }^{\mathrm{c}}$ Jerry Jasinski, ${ }^{\mathrm{c}}$ Nada Kheira \\ Sebbar $^{\mathrm{d}, \mathrm{e}}$ and Youssef Kandri Rodi ${ }^{\mathrm{a}}$
}

\begin{abstract}
a'Laboratoire de Chimie Organique Appliquée, Université Sidi Mohamed Ben Abdallah, Faculté des Sciences et Techniques, Route d'immouzzer, BP 2202, Fez, Morocco, 'b Department of Physics, Hacettepe University, 06800 Beytepe, Ankara, Turkey, ' Department of Chemistry, Keene State College, 229 Main Street, Keene, NH 03435-2001, USA, ${ }^{\mathbf{d}}$ Laboratoire de Chimie bioorganique appliquée, Faculté des sciences, Université Ibn Zohr, Agadir, Morocco, and 'Laboratoire de Chimie Organique Hétérocyclique URAC 21, Pôle de Compétence Pharmacochimie, Av. Ibn Battouta, BP 1014, Faculté des Sciences, Université Mohammed V, Rabat, Morocco. *Correspondence e-mail: yassir.filali.baba2018@gmail.com
\end{abstract}

The title compound, $\mathrm{C}_{24} \mathrm{H}_{24} \mathrm{~N}_{2} \mathrm{O}_{6}$, consists of ethyl 2-(1,2,3,4-tetrahydro-2-oxoquinolin-1-yl)acetate and 4-[(2-ethoxy-2-oxoethyl)(phenyl)carbomoyl] units, where the oxoquinoline unit is almost planar and the acetate substituent is nearly perpendicular to its mean plane. In the crystal, $\mathrm{C}-\mathrm{H}_{\mathrm{Oxqn}} \cdots \mathrm{O}_{\mathrm{Ethx}}$ and $\mathrm{C}-\mathrm{H}_{\text {Phyl }} \cdots \mathrm{O}_{\text {Carbx }}(\mathrm{Oxqn}=$ oxoquinolin, Ethx $=$ ethoxy, Phyl = phenyl and Carbx $=$ carboxylate) weak hydrogen bonds link the molecules into a threedimensional network sturucture. A $\pi-\pi$ interaction between the constituent rings of the oxoquinoline unit, with a centroid-centroid distance of 3.675 (1) $\AA$ may further stabilize the structure. Both terminal ethyl groups are disordered over two sets of sites. The ratios of the refined occupanies are 0.821 (8):0.179 (8) and 0.651 (18):0.349 (18). The Hirshfeld surface analysis of the crystal structure indicates that the most important contributions for the crystal packing are from $\mathrm{H} \cdots \mathrm{H}(53.9 \%), \mathrm{H} \cdots \mathrm{O} / \mathrm{O} \cdots \mathrm{H}(28.5 \%)$ and $\mathrm{H} \cdots \mathrm{C} / \mathrm{C} \cdots \mathrm{H}(11.8 \%)$ interactions. Weak intermolecular hydrogen-bond interactions and van der Waals interactions are the dominant interactions in the crystal packing. Density functional theory (DFT) geometric optimized structures at the B3LYP/6-311G(d,p) level are compared with the experimentally determined molecular structure in the solid state. The HOMO-LUMO molecular orbital behaviour was elucidated to determine the energy gap.

\section{Chemical context}

In recent years, research has been focused on existing molecules and their modifications in order to reduce their side effects and to explore their other pharmacological properties. Quinolone derivatives have constituted an important class of heterocyclic compounds which, even when part of a complex molecule, possesses a wide spectrum of biological activities, such as anticancer (Elderfield \& Le Von, 1960), antifungal (Musiol et al., 2010), antitubercular (Fan et al., 2018a; Xu et al., 2017), antimalarial (Fan et al., 2018b; Hu et al., 2017), anti-HIV (Sekgota et al., 2017; Luo et al., 2010), anti-HCV (Manfroni et al., 2014; Cheng et al., 2016) and antimicrobial (Musiol et al., 2006). They have been developed for the treatment of many diseases, like malaria (Lutz et al., 1946) and HIV (Ahmed et al., 2010). As a continuation of our research work devoted to the development of $\mathrm{N}$-substituted quinoline derivatives and 
Table 1

Hydrogen-bond geometry $\left(\AA,^{\circ}\right)$.

\begin{tabular}{lllll}
\hline$D-\mathrm{H} \cdots A$ & $D-\mathrm{H}$ & $\mathrm{H} \cdots A$ & $D \cdots A$ & $D-\mathrm{H} \cdots A$ \\
\hline $\mathrm{C} 7-\mathrm{H} 7 \cdots \mathrm{O}^{\mathrm{i}}$ & 0.95 & 2.46 & $3.404(2)$ & 171 \\
$\mathrm{C} 12 A-\mathrm{H} 12 D \cdots \mathrm{O}^{\mathrm{ii}}$ & 0.99 & 2.73 & $3.477(14)$ & 132 \\
$\mathrm{C}^{\mathrm{i}} 7 A-\mathrm{H} 17 C \cdots \mathrm{O}^{\text {iii }}$ & 0.99 & 2.73 & $3.377(17)$ & 124 \\
$\mathrm{C}^{2}-\mathrm{H} 22 \cdots 3^{\text {iv }}$ & 0.95 & 2.42 & $3.342(3)$ & 164 \\
\hline
\end{tabular}

Symmetry codes: (i) $x-\frac{1}{2},-y+1, z$; (ii) $-x+\frac{1}{2}, y,-z+1$; (iii) $x,-y+\frac{1}{2}, z-\frac{1}{2}$; (iv) $-x+1, y-\frac{1}{2},-z+\frac{1}{2}$.

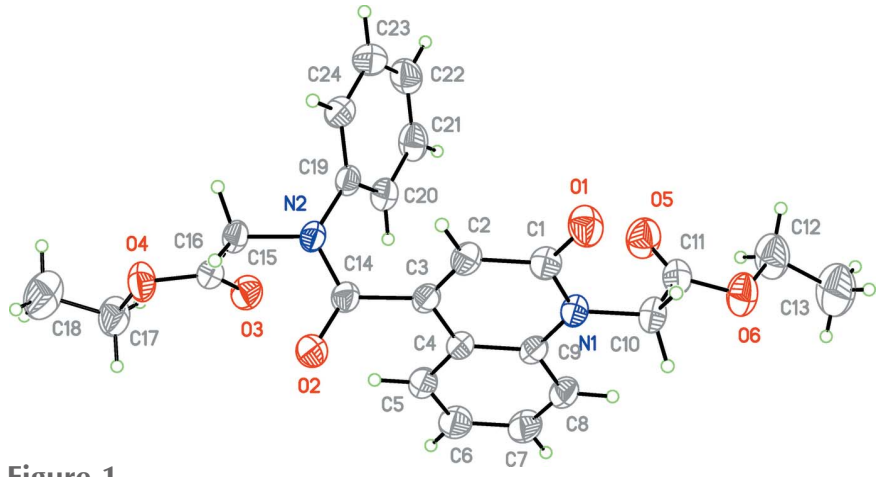

Figure 1

The molecular structure of the title compound, showing the atomnumbering scheme and displacement ellipsoids drawn at the $50 \%$ probability level. For the sake of clarity, the minor component of disorder is not shown.

the assessments of their potential pharmacological activities (Filali Baba et al., 2016a, 2017, 2019; Bouzian et al., 2018, $2019 a$ ), we report herein the synthesis and molecular and crystal structure of the title compound, along with the Hirshfeld surface (HS) analysis and density functional theory (DFT) computational calculations carried out at the B3LYP/6$311 \mathrm{G}(\mathrm{d}, \mathrm{p})$ level of an $\mathrm{N}$-substituted quinoline derivative by an alkylation reaction of ethyl bromoacetate with 2-oxo- $N$ phenyl-1,2-dihydroquinoline-4-carboxamide under phasetransfer catalysis conditions using tetra- $n$-butylammonium bromide (TBAB) as a catalyst and potassium carbonate as a base.

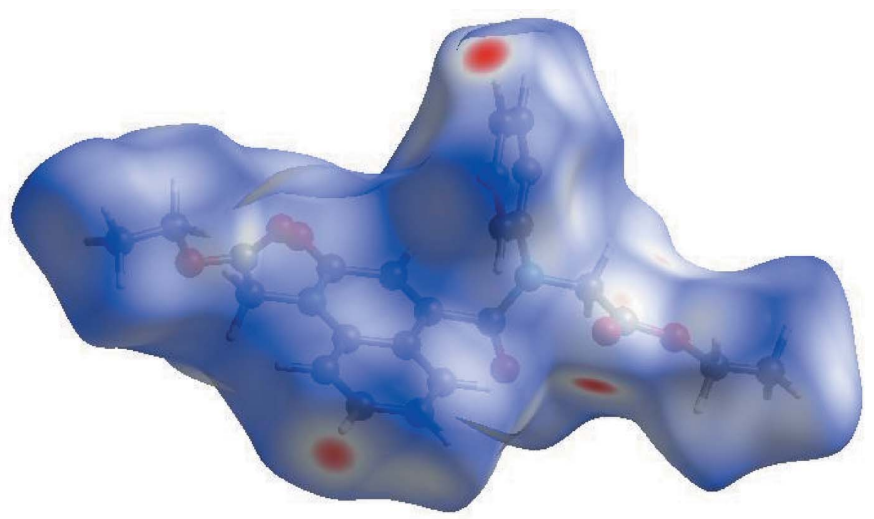

Figure 3

A view of the three-dimensional Hirshfeld surface for the title compound, plotted over $d_{\text {norm }}$ in the range -0.2380 to 1.5740 a.u.<smiles>CCOC(=O)CN(C(=O)c1cc(=O)n(CC(=O)OCC)c2ccccc12)c1ccccc1</smiles>

\section{Structural commentary}

The title molecule is composed of ethyl 2-(1,2,3,4-tetrahydro2-oxoquinolin-1-yl)acetate and 4-[(2-ethoxy-2-oxoethyl)(phenyl)carbomoyl] units (Fig. 1). The mean planes of the constituent rings, i.e. $A$ (atoms N1/C1-C4/C9) and $B$ (C4-C9), of the oxoquinoline unit are oriented at a dihedral angle of $1.04(6)^{\circ}$. Thus, they are almost coplanar, with a maximum

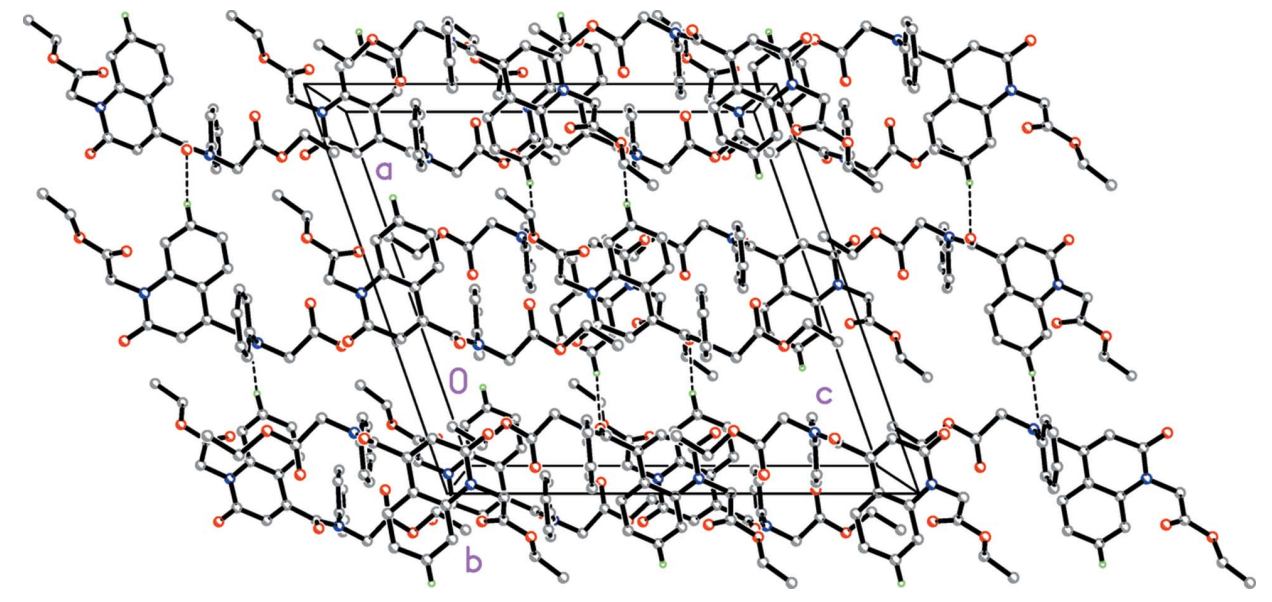

Figure 2

A partial packing diagram viewed along the $b$ axis. Weak $\mathrm{C}-\mathrm{H}_{\mathrm{Oxqn}} \cdots \mathrm{O}_{\mathrm{Ethx}}$ and $\mathrm{C}-\mathrm{H}_{\mathrm{Phyl}} \cdots \mathrm{O}_{\mathrm{Carbx}}(\mathrm{Oxqn}=$ oxoquinolin, Ethx $=$ ethoxy, $\mathrm{Phyl}=$ phenyl and Carbx $=$ carboxylate) intermolecular hydrogen bonds are shown as dashed lines. The disorder is not shown. 


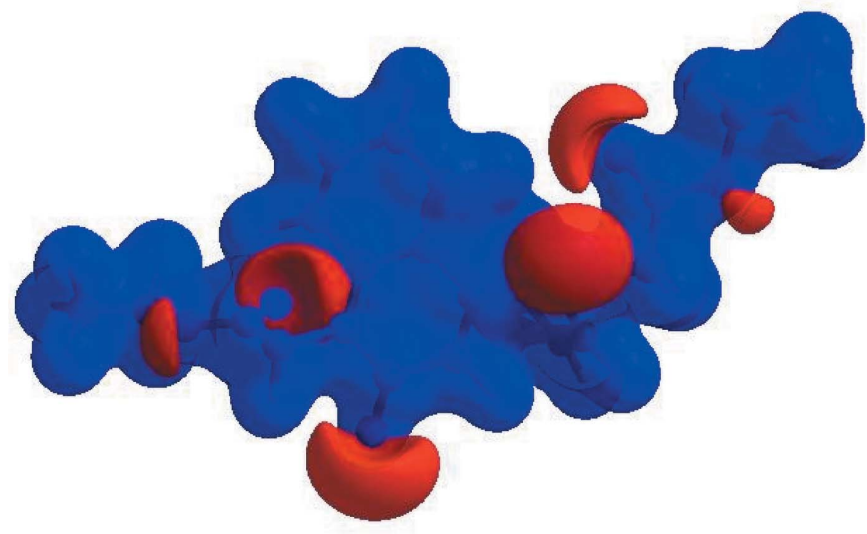

Figure 4

A view of the three-dimensional Hirshfeld surface of the title compound, plotted over the electrostatic potential energy in the range -0.0500 to 0.0500 a.u. using the STO-3G basis set at the Hartree-Fock level of theory. Weak hydrogen-bond donor and acceptor intermolecular interactions are shown as blue and red regions around the atoms corresponding to positive and negative potentials, respectively.

deviation of 0.017 (3) $\AA$ for atom C7. Atoms $\mathrm{O} 1$ and $\mathrm{C} 10$ deviate only by 0.007 (2) and 0.022 (2) $\AA$ from that plane and so are essential coplanar. The acetate substituent is nearly perpendicular to that plane, with a torsion angle of $\mathrm{C} 1-\mathrm{N} 1-$ $\mathrm{C} 10-\mathrm{C} 11=-104.8(2)^{\circ}$. The mean plane of the phenyl ring, $C$ (C19-C24), is oriented with respect to the oxoquinoline unit at a dihedral angle of $68.17(6)^{\circ}$. The carboxyl groups, O5/O6/ $\mathrm{C} 11$ and $\mathrm{O} 3 / \mathrm{O} 4 / \mathrm{C} 16$, are twisted out of coplanarity with the best least-squares plane of the oxoquinoline unit and phenyl ring $C$ by dihedral angles of 79.7 (2) and $62.9(2)^{\circ}$, respectively.

\section{Supramolecular features}

In the crystal, weak $\mathrm{C}-\mathrm{H}_{\mathrm{Oxqn}} \cdots \mathrm{O}_{\mathrm{Ethx}}$ and $\mathrm{C}-\mathrm{H}_{\text {Phyl }} \cdots \mathrm{O}_{\text {Carbx }}$ $($ Oxqn $=$ oxoquinolin, Ethx $=$ ethoxy, Phyl $=$ phenyl and Carbx = carboxylate) hydrogen bonds (Table 1) link the molecules into a three-dimensional network structure (Fig. 2). A $\pi-\pi$ contact between the constituent rings, i.e. $A$ (N1/C1$\mathrm{C} 4 / \mathrm{C} 9)$ and $B$ (C4-C9), of the oxoquinoline unit, with $C g 1 \cdots C g 2^{\mathrm{i}}=3.675$ (1) $\AA$ [symmetry code: (i) $-x+1,-y+1$, $-z+1 ; C g 1$ and $C g 2$ are the centroids of rings $A$ and $B]$, may further stabilize the structure. The Hirshfeld surface analysis of the crystal structure indicates that the most important contributions for crystal packing are from $\mathrm{H} \cdots \mathrm{H}(53.9 \%)$, $\mathrm{H} \cdots \mathrm{O} / \mathrm{O} \cdots \mathrm{H}(28.5 \%)$ and $\mathrm{H} \cdots \mathrm{C} / \mathrm{C} \cdots \mathrm{H}(11.8 \%)$ interactions. Weak intermolecular hydrogen-bond interactions and van der Waals interactions are the dominant interactions in the crystal packing.

\section{Hirshfeld surface analysis}

In order to visualize the intermolecular interactions in the title compound, a Hirshfeld surface (HS) analysis (Hirshfeld, 1977; Spackman \& Jayatilaka, 2009) was carried out by using CrystalExplorer17.5 (Turner et al., 2017). In the HS plotted over $d_{\text {norm }}$ (Fig. 3), the white surface indicates contacts with distances equal to the sum of the van der Waals radii, and the

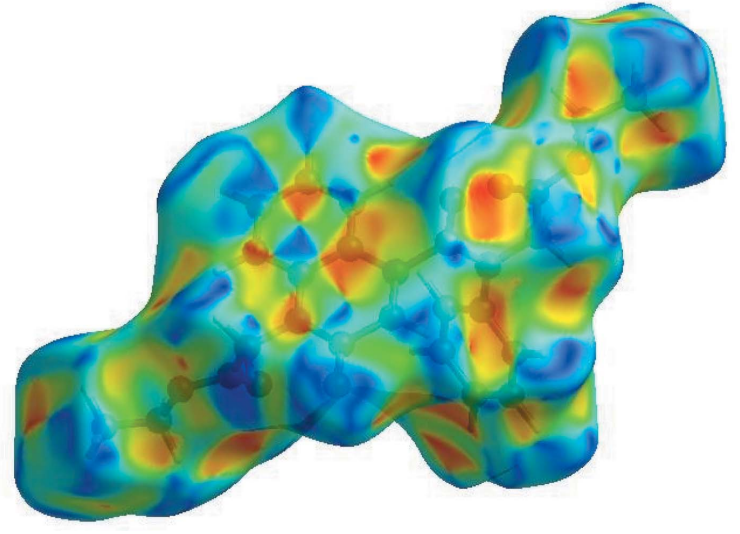

Figure 5

A view of the Hirshfeld surface for the title compound, plotted over the shape-index.

red and blue colours indicate distances shorter (in close contact) or longer (distinct contact) than the van der Waals radii, respectively (Venkatesan et al., 2016). The bright-red spots appearing near $\mathrm{O} 2$ and $\mathrm{H}$ atoms $\mathrm{H} 7$ and $\mathrm{H} 22$ indicate their roles as the respective donors and/or acceptors; they also appear as blue and red regions corresponding to positive and negative potentials on the HS mapped over the electrostatic potential (Spackman et al., 2008; Jayatilaka et al., 2005), as
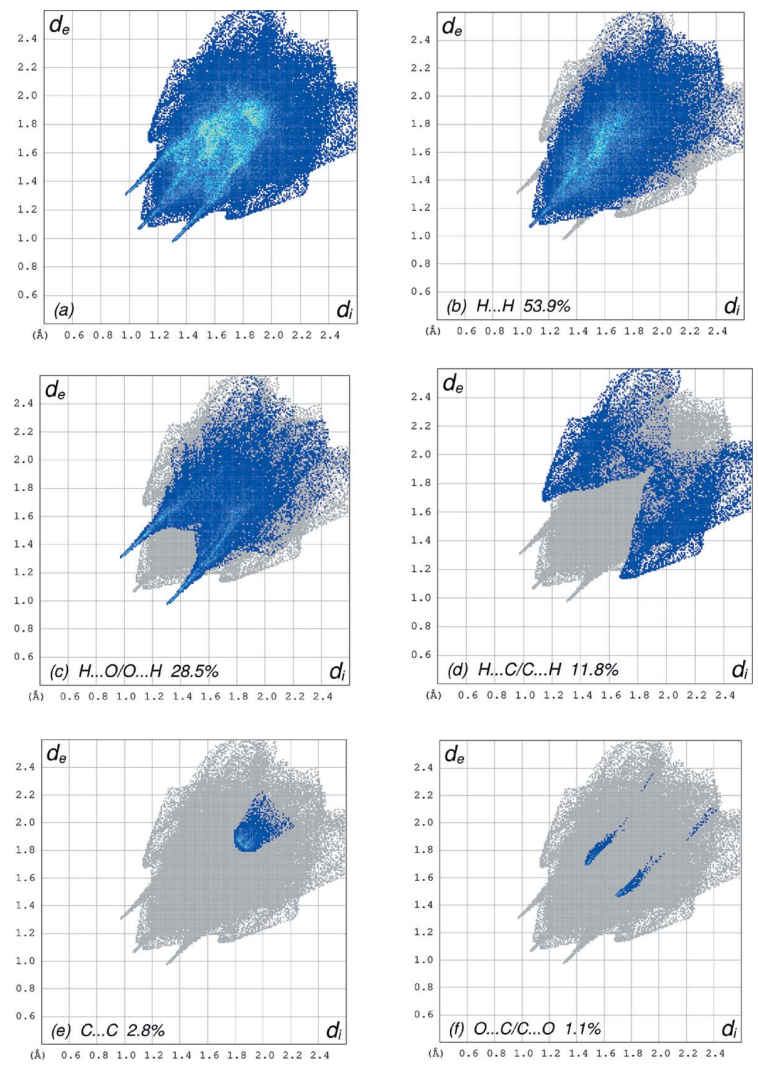

Figure 6

The full two-dimensional fingerprint plots for the title compound, showing $(a)$ all interactions, and delineated into $(b) \mathrm{H} \cdots \mathrm{H},(c) \mathrm{H} \cdots \mathrm{O} /$ $\mathrm{O} \cdots \mathrm{H},(d) \mathrm{H} \cdots \mathrm{C} / \mathrm{C} \cdots \mathrm{H},(e) \mathrm{C} \cdots \mathrm{C}$ and $(f) \mathrm{O} \cdots \mathrm{C} / \mathrm{C} \cdots \mathrm{O}$ interactions. The $d_{\mathrm{i}}$ and $d_{\mathrm{e}}$ values are the closest internal and external distances (in $\AA$ from given points on the Hirshfeld surface contacts. 
Table 2

Comparison of the selected (X-ray and DFT) geometric data $\left(\AA{ }^{\circ}\right)$.

\begin{tabular}{|c|c|c|}
\hline Bonds/angles & X-ray & B3LYP/6-311G(d,p) \\
\hline $\mathrm{O} 1-\mathrm{C} 1$ & $1.226(2)$ & 1.23817 \\
\hline $\mathrm{O} 2-\mathrm{C} 14$ & $1.225(2)$ & 1.23404 \\
\hline $\mathrm{O} 3-\mathrm{C} 16$ & $1.199(2)$ & 1.20354 \\
\hline $\mathrm{O} 4-\mathrm{C} 16$ & $1.324(2)$ & 1.36931 \\
\hline $\mathrm{O} 4-\mathrm{C} 17$ & $1.487(4)$ & 1.48849 \\
\hline $\mathrm{O} 5-\mathrm{C} 11$ & $1.193(3)$ & 1.22578 \\
\hline $\mathrm{O} 6-\mathrm{C} 11$ & $1.317(3)$ & 1.38125 \\
\hline $\mathrm{O} 6-\mathrm{C} 12$ & $1.476(4)$ & 1.47909 \\
\hline $\mathrm{N} 1-\mathrm{C} 1$ & $1.381(2)$ & 1.41268 \\
\hline $\mathrm{N} 1-\mathrm{C} 9$ & $1.390(3)$ & 1.40270 \\
\hline $\mathrm{N} 1-\mathrm{C} 10$ & $1.457(2)$ & 1.45920 \\
\hline $\mathrm{N} 2-\mathrm{C} 14$ & $1.349(2)$ & 1.38292 \\
\hline $\mathrm{N} 2-\mathrm{C} 15$ & $1.455(2)$ & 1.46732 \\
\hline $\mathrm{N} 2-\mathrm{C} 19$ & $1.437(2)$ & 1.43915 \\
\hline $\mathrm{C} 16-\mathrm{O} 4-\mathrm{C} 17$ & $115.0(3)$ & 117.00006 \\
\hline $\mathrm{C} 11-\mathrm{O} 6-\mathrm{C} 12$ & $115.0(2)$ & 117.92667 \\
\hline $\mathrm{C} 1-\mathrm{N} 1-\mathrm{C} 9$ & $123.54(14)$ & 123.13299 \\
\hline $\mathrm{C} 1-\mathrm{N} 1-\mathrm{C} 10$ & $116.70(15)$ & 115.18860 \\
\hline $\mathrm{C} 9-\mathrm{N} 1-\mathrm{C} 10$ & $119.72(15)$ & 120.66132 \\
\hline $\mathrm{C} 14-\mathrm{N} 2-\mathrm{C} 15$ & $116.96(15)$ & 115.85567 \\
\hline $\mathrm{C} 14-\mathrm{N} 2-\mathrm{C} 19$ & $124.11(13)$ & 125.08748 \\
\hline $\mathrm{C} 19-\mathrm{N} 2-\mathrm{C} 15$ & $117.61(14)$ & 119.01375 \\
\hline $\mathrm{O} 1-\mathrm{C} 1-\mathrm{N} 1$ & $121.49(17)$ & 120.57635 \\
\hline $\mathrm{O} 1-\mathrm{C} 1-\mathrm{C} 2$ & $123.02(17)$ & 123.38727 \\
\hline $\mathrm{N} 1-\mathrm{C} 1-\mathrm{C} 2$ & $115.48(16)$ & 116.01507 \\
\hline
\end{tabular}

shown in Fig. 4. The blue regions indicate a positive electrostatic potential (hydrogen-bond donors), while the red regions indicate a negative electrostatic potential (hydrogen-bond acceptors). The shape-index of the HS is a tool to visualize the $\pi-\pi$ stacking by the presence of adjacent red and blue triangles; if there are no adjacent red and/or blue triangles, then there are no $\pi-\pi$ interactions. Fig. 5 clearly suggests that there are $\pi-\pi$ interactions in (I). The overall two-dimensional
Table 3

Calculated energies.

\begin{tabular}{ll}
\hline Molecular Energy (a.u.) (eV) & Compound (I) \\
\hline Total Energy $T E(\mathrm{eV})$ & -40528.2845 \\
$E_{\mathrm{HOMO}}(\mathrm{eV})$ & -6.1141 \\
$E_{\mathrm{Lumo}}(\mathrm{eV})$ & -1.9050 \\
Gap $\Delta E(\mathrm{eV})$ & 4.2091 \\
Dipole moment $\mu(\mathrm{Debye})$ & 7.7590 \\
Ionization potential $I(\mathrm{eV})$ & 6.1141 \\
Electron affinity $A$ & 1.9050 \\
Electro negativity $\chi$ & 4.0095 \\
Hardness $\eta$ & 2.1046 \\
Electrophilicity index $\omega$ & 3.8194 \\
Softness $\sigma$ & 0.4752 \\
Fraction of electron transferred $\Delta N$ & 0.7105
\end{tabular}

fingerprint plot (Fig. 6a) and those delineated into $\mathrm{H} \cdots \mathrm{H}$, $\mathrm{H} \cdots \mathrm{O} / \mathrm{O} \cdots \mathrm{H}, \quad \mathrm{H} \cdots \mathrm{C} / \mathrm{C} \cdots \mathrm{H}, \quad \mathrm{C} \cdots \mathrm{C}$ and $\mathrm{O} \cdots \mathrm{C} / \mathrm{C} \cdots \mathrm{O}$ contacts (McKinnon et al., 2007) are illustrated in Figs. 6(b)$(f)$, respectively, together with their relative contributions to the Hirshfeld surface. The most important interaction is $\mathrm{H} \cdots \mathrm{H}$, contributing $53.9 \%$ to the overall crystal packing, which is reflected in Fig. 6(b) as widely scattered points of high density due to the large hydrogen content of the molecule, with the tip at $d_{\mathrm{e}}=d_{\mathrm{i}}=1.05 \AA$, due to the short interatomic $\mathrm{H} \cdot \mathrm{H}$ contacts. The pair of characteristic wings resulting in the fingerprint plot delineated into $\mathrm{H} \cdots \mathrm{O} / \mathrm{O} \cdots \mathrm{H}$ contacts (Fig. $6 c$ ) has a $28.5 \%$ contribution to the $\mathrm{HS}$ and is viewed as a pair of spikes with the tips at $d_{\mathrm{e}}+d_{\mathrm{i}}=2.30 \AA$. In the absence of weak $\mathrm{C}-\mathrm{H} \cdots \pi$ interactions, the pair of characteristic wings resulting in the fingerprint plot delineated into $\mathrm{H} \cdots \mathrm{C} / \mathrm{C} \cdots \mathrm{H}$ contacts (Fig. $6 d$ ), with a $11.8 \%$ contribution to the $\mathrm{HS}$ and are viewed as a pair of spikes with the tip at $d_{\mathrm{e}}+d_{\mathrm{i}}=2.83 \AA$. The

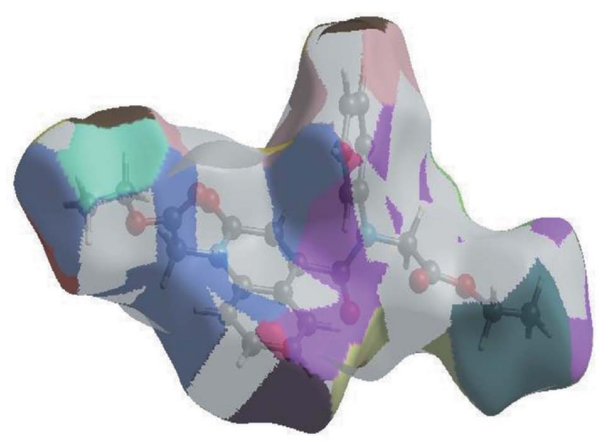

(a)

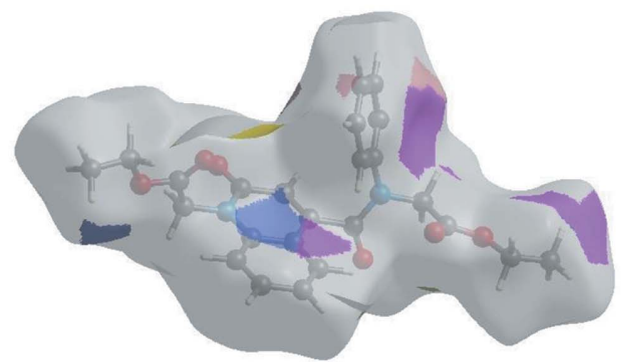

(c)

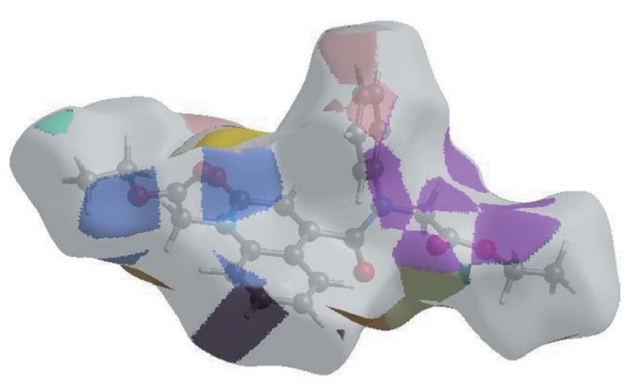

(b)

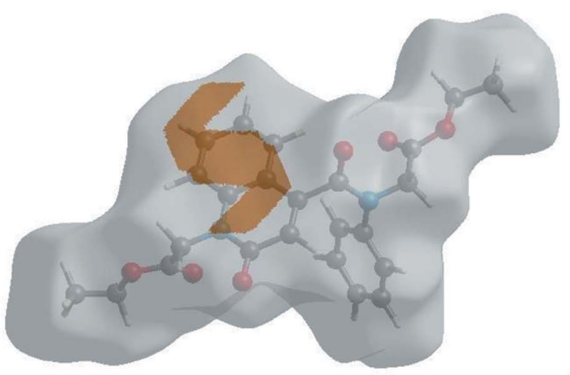

(d)

Figure 7

The Hirshfeld surface representations with the function $d_{\text {norm }}$ plotted onto the surface for $(a) \mathrm{H} \cdots \mathrm{H},(b) \mathrm{H} \cdots \mathrm{O} / \mathrm{O} \cdots \mathrm{H},(c) \mathrm{H} \cdots \mathrm{C} / \mathrm{C} \cdots \mathrm{H}$ and $(d) \mathrm{C} \cdots \mathrm{C}$ interactions. 
C. . C contacts (Fig. 6e) have an arrow-shaped distribution of points with the tip at $d_{\mathrm{e}}=d_{\mathrm{i}}=1.81 \AA$. Finally, the pair of the scattered points of wings from the fingerprint plot are delineated into $\mathrm{O} \cdots \mathrm{C} / \mathrm{C} \cdots \mathrm{O}$ (Fig. $6 f$ ) contacts, with a $1.1 \%$ contribution to the HS, and has a nearly symmetrical distribution of points with the edges at $d_{\mathrm{e}}+d_{\mathrm{i}}=3.15 \AA$.

The Hirshfeld surface representations with the function $d_{\text {norm }}$ plotted onto the surface are shown for the $\mathrm{H} \cdots \mathrm{H}$, $\mathrm{H} \cdots \mathrm{O} / \mathrm{O} \cdots \mathrm{H}, \quad \mathrm{H} \cdots \mathrm{C} / \mathrm{C} \cdots \mathrm{H}$ and $\mathrm{C} \cdots \mathrm{C}$ interactions in Figs. 7(a) $-(d)$, respectively.

The Hirshfeld surface analysis confirms the importance of weak $\mathrm{H}$-atom contacts in establishing the packing structure. The large number of $\mathrm{H} \cdots \mathrm{H}, \mathrm{H} \cdots \mathrm{O} / \mathrm{O} \cdots \mathrm{H}$ and $\mathrm{H} \cdots \mathrm{C} / \mathrm{C} \cdots \mathrm{H}$ interactions suggest that van der Waals interactions and weak hydrogen-bond intermolecular interactions play major roles in the crystal packing (Hathwar et al., 2015).

\section{DFT calculations}

The geometry optimized structure of the title compound in the gas phase was generated theoretically via density functional theory (DFT) computational calculations using a standard B3LYP functional and a 6-311G(d,p) basis set (Becke, 1993), as implemented in GAUSSIAN09 (Frisch et al., 2009). The theoretical and experimental results were in good agreement (Table 2). A DFT molecular orbital calculation indicated that the highest-occupied molecular orbital (HOMO), acting as an electron donor, and the lowest-unoccupied molecular orbital (LUMO), acting as an electron acceptor, are very important parameters for quantum chemistry. When the energy gap is small, the molecule is highly polarizable and has high chemical reactivity. Therefore, these DFT calculations provide important information on the reactivity and site selectivity of the molecular framework. $E_{\mathrm{HOMO}}$ and $E_{\mathrm{LUMO}}$ clarify the inevitable charge exchange collaboration inside the studied material, as well as electronegativity $(\chi)$, hardness $(\eta)$, potential $(\mu)$, electrophilicity $(\omega)$ and softness $(\sigma)$, which are listed in Table 3. The significance of $\eta$ and $\sigma$ is to evaluate both reactivity and stability. The electron transition from a HOMO to a LUMO energy level is shown in Fig. 8. The HOMO and LUMO are localized in the plane extending from the whole ethyl 2-\{4-[(2-ethoxy-2-oxoethyl)(phenyl)carbamoyl]-2-oxo1,2-dihydroquinolin-1-yl\}acetate ring. The energy band gap [ $\left.\Delta E=E_{\mathrm{LUMO}}-E_{\mathrm{HOMO}}\right]$ of the molecule was about $4.2091 \mathrm{eV}$, and the frontier molecular orbital (FMO) energies, i.e. $E_{\mathrm{HOMO}}$ and $E_{\mathrm{LUMO}}$, were -6.1141 and $-1.9050 \mathrm{eV}$, respectively.

\section{Database survey}

A non-alkylated analogue, namely quinoline and its derivatives, has been reported (Filali Baba et al., 2016b, 2017; Bouzian et al., 2019a), as well as three similar structures (see Castañeda et al., 2014; Kafka et al., 2012; Bouzian et al., 2018, 2019a; Divya Bharathi et al., 2015).

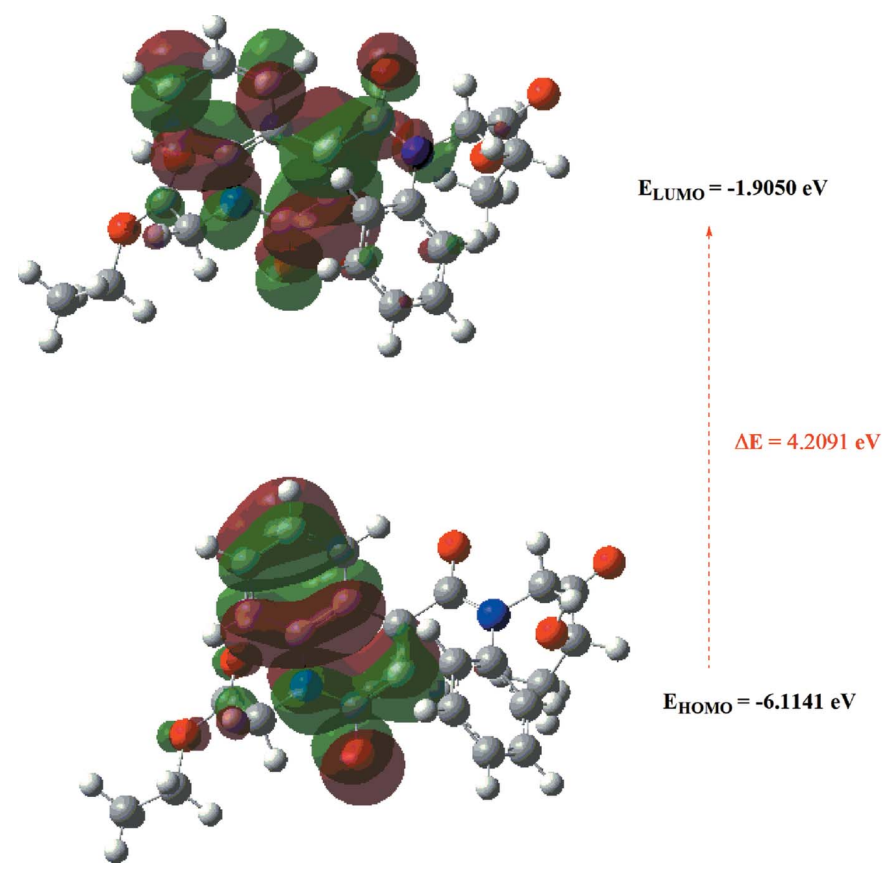

Figure 8

The calculated energy band gap for the title compound.

\section{Synthesis and crystallization}

To a solution of 2-oxo- $N$-phenyl-1,2-dihydroquinoline-4carboxamide $(1.89 \mathrm{mmol})$ in dimethylformamide (DMF, $10 \mathrm{ml}$ ) were added ethyl bromoacetate $(4.16 \mathrm{mmol}), \mathrm{K}_{2} \mathrm{CO}_{3}$ $(5.67 \mathrm{mmol})$ and tetrabutylammonium bromide (TBAB, $0.23 \mathrm{mmol}$ ). The reaction mixture was stirred at room temperature for $6 \mathrm{~h}$. After removal of the salts by filtration, the DMF was evaporated under reduced pressure and the resulting residue was dissolved in dichloromethane. The organic phase was dried with $\mathrm{Na}_{2} \mathrm{SO}_{4}$ and then concentrated under reduced pressure. The pure compound was obtained by column chromatography using as eluate hexane/ethyl acetate $(3: 1 \mathrm{v} / \mathrm{v})$. The isolated solid was recrystallized from hexanediethyl acetate $(1: 1 \mathrm{v} / \mathrm{v})$ to afford colourless crystals (yield $75 \%$; m.p. 427 K).

\section{Refinement}

The experimental details, including the crystal data, data collection and refinement, are summarized in Table $4 . \mathrm{H}$ atoms were positioned geometrically, with $\mathrm{C}-\mathrm{H}=0.93,0.97$ and $0.96 \AA$ for aromatic $\mathrm{CH}, \mathrm{CH}_{2}$ and $\mathrm{CH}_{3} \mathrm{H}$ atoms, respectively, and constrained to ride on their parent atoms, with $U_{\text {iso }}(\mathrm{H})=$ $k U_{\text {eq }}(\mathrm{C})$, where $k=1.5$ for $\mathrm{CH}_{3} \mathrm{H}$ atoms and $k=1.2$ for other $\mathrm{H}$ atoms. The terminal ethyl groups are disordered with an occupancy ratio of 0.821 (8):0.179 (8) for $\mathrm{C} 12$ and $\mathrm{C} 13$, and 0.651 (18):0.349 (18) for $\mathrm{C} 17$ and $\mathrm{C} 18$.

\section{Funding information}

Funding for this research was provided by: NSF-MRI (grant No. CHE-1039027 to purchase the X-ray diffractometer, 
acknowledged by JPJ); Hacettepe University Scientific Research Project Unit (grant No. 013 D04 602 004, to TH).

\section{References}

Ahmed, N., Brahmbhatt, K. G., Sabde, S., Mitra, D., Singh, I. P. \& Bhutani, K. K. (2010). Bioorg. Med. Chem. 18, 2872-2879.

Becke, A. D. (1993). J. Chem. Phys. 98, 5648-5652.

Bouzian, Y., Hlimi, F., Sebbar, N. K., El Hafi, M., Hni, B., Essassi, E. M. \& Mague, J. T. (2018). IUCrData, 3, x181438.

Bouzian, Y., Karrouchi, K., Anouar, E. H., Bouhfid, R., Arshad, S. \& Essassi, E. M. (2019a). Acta Cryst. E75, 912-916.

Castañeda, R., Antal, S. A., Draguta, S., Timofeeva, T. V. \& Khrustalev, V. N. (2014). Acta Cryst. E70, o924-o925.

Cheng, Y., Shen, J., Peng, R. Z., Wang, G. F., Zuo, J. P. \& Long, Y. Q. (2016). Bioorg. Med. Chem. Lett. 26, 2900-2906.

Divya Bharathi, M., Ahila, G., Mohana, J., Chakkaravarthi, G. \& Anbalagan, G. (2015). Acta Cryst. E71, o261-0262.

Dolomanov, O. V., Bourhis, L. J., Gildea, R. J., Howard, J. A. K. \& Puschmann, H. (2009). J. Appl. Cryst. 42, 339-341.

Elderfield, R. C. \& Le Von, E. F. (1960). J. Org. Chem. 25, 1576-1583.

Fan, Y. L., Cheng, X. W., Wu, J. B., Liu, M., Zhang, F. Z., Xu, Z. \& Feng, L. S. (2018b). Eur. J. Med. Chem. 146, 1-14.

Fan, Y. L., Wu, J. B., Cheng, X. W., Zhang, F. Z. \& Feng, L. S. (2018a). Eur. J. Med. Chem. 146, 554-563.

Filali Baba, Y., Elmsellem, H., KandriRodi, Y., Steli, H., AD, C., Ouzidan, Y., Ouazzani Chahdi, F., Sebbar, N. K., Essassi, E. M. \& Hammouti, B. (2016a). Pharma Chem. 8, 159-169.

Filali Baba, Y., Kandri Rodi, Y., Ouzidan, Y., Mague, J. T., Ouazzani Chahdi, F. \& Essassi, E. M. (2017). IUCrData, 2, x171038.

Filali Baba, Y., Mague, J. T., Kandri Rodi, Y., Ouzidan, Y., Essassi, E. M. \& Zouihri, H. (2016b). IUCrData, 1, x160997.

Filali Baba, Y., Sert, Y., Kandri Rodi, Y., Hayani, S., Mague, J. T., Prim, D., Marrot, J., Ouazzani Chahdi, F., Sebbar, N. K. \& Essassi, E. M. (2019). J. Mol. Struct. 1188, 255-268.

Frisch, M. J., Trucks, G. W., Schlegel, H. B., Scuseria, G. E., Robb, M. A., Cheeseman, J. R., et al. (2009). GAUSSIAN09. Gaussian Inc., Wallingford, CT, USA.

Hathwar, V. R., Sist, M., Jørgensen, M. R. V., Mamakhel, A. H., Wang, X., Hoffmann, C. M., Sugimoto, K., Overgaard, J. \& Iversen, B. B. (2015). IUCrJ, 2, 563-574.

Hirshfeld, H. L. (1977). Theor. Chim. Acta, 44, 129-138.

Hu, Y. Q., Gao, C., Zhang, S., Xu, L., Xu, Z., Feng, L. S., Wu, X. \& Zhao, F. (2017). Eur. J. Med. Chem. 139, 22-47.

Jayatilaka, D., Grimwood, D. J., Lee, A., Lemay, A., Russel, A. J., Taylor, C., Wolff, S. K., Cassam-Chenai, P. \& Whitton, A. (2005). TONTO - A System for Computational Chemistry. Available at: http://hirshfeldsurface.net/.

Kafka, S., Pevec, A., Proisl, K., Kimmel, R. \& Kosmrlj, J. (2012). Acta Cryst. E68, o3199-o3200.

Luo, Z. G., Tan, J. J., Zeng, Y., Wang, C. X. \& Hu, L. M. (2010). Mini Rev. Med. Chem. 10, 1046-1057.

Lutz, R. E., Bailey, P. S., Clark, M. T., Codington, J. F., Deinet, A. J., Freek, J. A., Harnest, G. H., Leake, N. H., Martin, T. A., Rowlett, R. J., Salsbury, J. M., Shearer, N. H., Smith, J. D. \& Wilson, J. W. (1946). J. Am. Chem. Soc. 68, 1813-1831.

Manfroni, G., Cannalire, R., Barreca, M. L., Kaushik-Basu, N., Leyssen, P., Winquist, J., Iraci, N., Manvar, D., Paeshuyse, J., Guhamazumder, R., Basu, A., Sabatini, S., Tabarrini, O., Danielson, U. H., Neyts, J. \& Cecchetti, V. (2014). J. Med. Chem. 57, 1952-1963.
Table 4

Experimental details.

\begin{tabular}{|c|c|}
\hline \multicolumn{2}{|l|}{ Crystal data } \\
\hline Chemical formula & $\mathrm{C}_{24} \mathrm{H}_{24} \mathrm{~N}_{2} \mathrm{O}_{6}$ \\
\hline$M_{\mathrm{r}}$ & 436.45 \\
\hline Crystal system, space group & Monoclinic, $I 2 / a$ \\
\hline Temperature $(\mathrm{K})$ & 173 \\
\hline$a, b, c(\AA)$ & $\begin{array}{l}16.9368(5), 15.4130(4) \\
18.4562(6)\end{array}$ \\
\hline$\beta\left(^{\circ}\right)$ & $109.254(4)$ \\
\hline$V\left(\AA^{3}\right)$ & $4548.4(3)$ \\
\hline$Z$ & 8 \\
\hline Radiation type & $\mathrm{Cu} K \alpha$ \\
\hline$\mu\left(\mathrm{mm}^{-1}\right)$ & 0.76 \\
\hline Crystal size (mm) & $0.32 \times 0.22 \times 0.14$ \\
\hline \multicolumn{2}{|l|}{ Data collection } \\
\hline Diffractometer & $\begin{array}{l}\text { Rigaku Oxford Diffraction Eos } \\
\text { Gemini }\end{array}$ \\
\hline Absorption correction & $\begin{array}{l}\text { Multi-scan (CrysAlis PRO; Rigaku } \\
\quad \text { OD, 2015) }\end{array}$ \\
\hline$T_{\min }, T_{\max }$ & $0.710,1.000$ \\
\hline $\begin{array}{l}\text { No. of measured, independent and } \\
\text { observed }[I>2 \sigma(I)] \text { reflections }\end{array}$ & $8786,4337,3273$ \\
\hline$R_{\text {int }}$ & 0.018 \\
\hline$(\sin \theta / \lambda)_{\max }\left(\AA^{-1}\right)$ & 0.613 \\
\hline \multicolumn{2}{|l|}{ Refinement } \\
\hline$R\left[F^{2}>2 \sigma\left(F^{2}\right)\right], w R\left(F^{2}\right), S$ & $0.045,0.144,1.05$ \\
\hline No. of reflections & 4337 \\
\hline No. of parameters & 327 \\
\hline No. of restraints & 92 \\
\hline $\mathrm{H}$-atom treatment & $\mathrm{H}$-atom parameters constrained \\
\hline$\Delta \rho_{\max }, \Delta \rho_{\min }\left(\mathrm{e} \AA^{-3}\right)$ & $0.22,-0.13$ \\
\hline
\end{tabular}

Computer programs: CrysAlis PRO (Rigaku OD, 2015), SHELXT (Sheldrick, 2015b), SHELXL2018 (Sheldrick, 2015a) and OLEX2 (Dolomanov et al., 2009).

McKinnon, J. J., Jayatilaka, D. \& Spackman, M. A. (2007). Chem. Commun. pp. 3814-3816.

Musiol, R., Jampilek, J., Buchta, V., Silva, L., Niedbala, H., Podeszwa, B., Palka, A., Majerz-Maniecka, K., Oleksyn, B. \& Polanski, J. (2006). Bioorg. Med. Chem. 14, 3592-3598.

Musiol, R., Serda, M., Hensel-Bielowka, S. \& Polanski, J. (2010). Curr. Med. Chem. 17, 1960-1973.

Rigaku OD (2015). CrysAlis PRO. Rigaku Americas, The Woodlands, TX, USA.

Sekgota, K. C., Majumder, S., Isaacs, M., Mnkandhla, D., Hoppe, H. C., Khanye, S. D., Kriel, F. H., Coates, J. \& Kaye, P. T. (2017). Bioorg. Chem. 75, 310-316.

Sheldrick, G. M. (2015a). Acta Cryst. A71, 3-8.

Sheldrick, G. M. (2015b). Acta Cryst. C71, 3-8.

Spackman, M. A. \& Jayatilaka, D. (2009). CrystEngComm, 11, 19-32.

Spackman, M. A., McKinnon, J. J. \& Jayatilaka, D. (2008). CrystEngComm, 10, 377-388.

Turner, M. J., McKinnon, J. J., Wolff, S. K., Grimwood, D. J., Spackman, P. R., Jayatilaka, D. \& Spackman, M. A. (2017). CrystalExplorer17. The University of Western Australia.

Venkatesan, P., Thamotharan, S., Ilangovan, A., Liang, H. \& Sundius, T. (2016). Spectrochim. Acta A Mol. Biomol. Spectrosc. 153, 625636.

Xu, Z., Song, X. F., Hu, Y. Q., Qiang, M. \& Lv, Z. S. (2017). Eur. J. Med. Chem. 138, 66-71. 


\section{supporting information}

Acta Cryst. (2019). E75, 1753-1758 [https://doi.org/10.1107/S2056989019014154]

Crystal structure, Hirshfeld surface analysis and DFT studies of ethyl 2-\{4-[(2ethoxy-2-oxoethyl)(phenyl)carbamoyl]-2-oxo-1,2-dihydroquinolin-1-yl\}acetate

Yassir Filali Baba, Sonia Hayani, Tuncer Hökelek, Manpreet Kaur, Jerry Jasinski, Nada Kheira

Sebbar and Youssef Kandri Rodi

Computing details

Data collection: CrysAlis PRO (Rigaku OD, 2015); cell refinement: CrysAlis PRO (Rigaku OD, 2015); data reduction: CrysAlis PRO (Rigaku OD, 2015); program(s) used to solve structure: SHELXT (Sheldrick, 2015b); program(s) used to refine structure: SHELXL2018 (Sheldrick, 2015a); molecular graphics: OLEX2 (Dolomanov et al., 2009); software used to prepare material for publication: OLEX2 (Dolomanov et al., 2009).

Ethyl 2-\{4-[(2-ethoxy-2-oxoethyl)(phenyl)carbamoyl]-2-oxo-1,2- $\backslash$ dihydroquinolin-1-yl\}acetate

Crystal data

$\mathrm{C}_{24} \mathrm{H}_{24} \mathrm{~N}_{2} \mathrm{O}_{6}$

$M_{r}=436.45$

Monoclinic, $I 2 / a$

$a=16.9368(5) \AA$

$b=15.4130(4) \AA$

$c=18.4562(6) \AA$

$\beta=109.254(4)^{\circ}$

$V=4548.4(3) \AA^{3}$

$Z=8$

\section{Data collection}

Rigaku Oxford Diffraction Eos Gemini diffractometer

Detector resolution: 16.0416 pixels $\mathrm{mm}^{-1}$

$\omega$ scans

Absorption correction: multi-scan

(CrysAlis PRO; Rigaku OD, 2015)

$T_{\min }=0.710, T_{\max }=1.000$

8786 measured reflections

\section{Refinement}

Refinement on $F^{2}$

Least-squares matrix: full

$R\left[F^{2}>2 \sigma\left(F^{2}\right)\right]=0.045$

$w R\left(F^{2}\right)=0.144$

$S=1.05$

4337 reflections

327 parameters

92 restraints
$F(000)=1840$

$D_{\mathrm{x}}=1.275 \mathrm{Mg} \mathrm{m}^{-3}$

$\mathrm{Cu} K \alpha$ radiation, $\lambda=1.54184 \AA$

Cell parameters from 3291 reflections

$\theta=4.0-71.1^{\circ}$

$\mu=0.76 \mathrm{~mm}^{-1}$

$T=173 \mathrm{~K}$

Prism, colourless

$0.32 \times 0.22 \times 0.14 \mathrm{~mm}$

4337 independent reflections

3273 reflections with $I>2 \sigma(I)$

$R_{\text {int }}=0.018$

$\theta_{\text {max }}=71.0^{\circ}, \theta_{\text {min }}=3.8^{\circ}$

$h=-20 \rightarrow 20$

$k=-16 \rightarrow 18$

$l=-22 \rightarrow 14$

Hydrogen site location: inferred from neighbouring sites

$\mathrm{H}$-atom parameters constrained

$w=1 /\left[\sigma^{2}\left(F_{0}^{2}\right)+(0.073 P)^{2}+1.2218 P\right]$

where $P=\left(F_{\mathrm{o}}{ }^{2}+2 F_{\mathrm{c}}{ }^{2}\right) / 3$

$(\Delta / \sigma)_{\max }<0.001$

$\Delta \rho_{\max }=0.22 \mathrm{e}^{-3}$

$\Delta \rho_{\min }=-0.13$ e $\AA^{-3}$ 


\section{Special details}

Geometry. All esds (except the esd in the dihedral angle between two 1.s. planes) are estimated using the full covariance matrix. The cell esds are taken into account individually in the estimation of esds in distances, angles and torsion angles; correlations between esds in cell parameters are only used when they are defined by crystal symmetry. An approximate (isotropic) treatment of cell esds is used for estimating esds involving l.s. planes.

Fractional atomic coordinates and isotropic or equivalent isotropic displacement parameters $\left(\AA^{2}\right)$

\begin{tabular}{|c|c|c|c|c|c|}
\hline & $x$ & $y$ & $z$ & $U_{\text {iso }} * / U_{\text {eq }}$ & Occ. $(<1)$ \\
\hline $\mathrm{O} 1$ & $0.63298(9)$ & $0.28034(12)$ & $0.61795(9)$ & $0.0789(4)$ & \\
\hline $\mathrm{O} 2$ & $0.63302(9)$ & $0.47704(9)$ & $0.36302(9)$ & $0.0744(4)$ & \\
\hline $\mathrm{O} 3$ & $0.53817(8)$ & $0.38810(10)$ & $0.18865(9)$ & $0.0758(4)$ & \\
\hline $\mathrm{O} 4$ & $0.64912(9)$ & $0.42678(11)$ & $0.15548(9)$ & $0.0788(4)$ & \\
\hline O5 & $0.40565(12)$ & $0.20343(12)$ & $0.53243(11)$ & $0.0931(5)$ & \\
\hline O6 & $0.37031(11)$ & $0.24950(13)$ & $0.63200(10)$ & $0.0916(5)$ & \\
\hline N1 & $0.51128(9)$ & $0.34488(10)$ & $0.54667(8)$ & $0.0550(4)$ & \\
\hline $\mathrm{N} 2$ & $0.63939(9)$ & $0.33627(9)$ & $0.33178(9)$ & $0.0531(3)$ & \\
\hline $\mathrm{C} 1$ & $0.59207(11)$ & $0.31706(13)$ & $0.55847(11)$ & $0.0580(4)$ & \\
\hline $\mathrm{C} 2$ & $0.62452(11)$ & $0.33490(12)$ & $0.49639(11)$ & $0.0583(4)$ & \\
\hline $\mathrm{H} 2$ & 0.679690 & 0.316531 & 0.501696 & $0.070^{*}$ & \\
\hline $\mathrm{C} 3$ & $0.58017(10)$ & $0.37609(11)$ & $0.43198(11)$ & $0.0517(4)$ & \\
\hline $\mathrm{C} 4$ & $0.49587(11)$ & $0.40413(11)$ & $0.42129(10)$ & $0.0510(4)$ & \\
\hline $\mathrm{C} 5$ & $0.44640(13)$ & $0.44579(14)$ & $0.35437(12)$ & $0.0660(5)$ & \\
\hline H5 & 0.468954 & 0.457597 & 0.314607 & $0.079^{*}$ & \\
\hline C6 & $0.36578(14)$ & $0.46981(16)$ & $0.34545(14)$ & $0.0793(6)$ & \\
\hline H6 & 0.332464 & 0.498023 & 0.299848 & $0.095^{*}$ & \\
\hline $\mathrm{C} 7$ & $0.33343(13)$ & $0.45228(17)$ & $0.40416(14)$ & $0.0794(6)$ & \\
\hline $\mathrm{H} 7$ & 0.277547 & 0.468683 & 0.398124 & $0.095^{*}$ & \\
\hline $\mathrm{C} 8$ & $0.38016(13)$ & $0.41215(14)$ & $0.46997(13)$ & $0.0670(5)$ & \\
\hline $\mathrm{H} 8$ & 0.356741 & 0.401356 & 0.509326 & $0.080^{*}$ & \\
\hline C9 & $0.46250(11)$ & $0.38660(11)$ & $0.48024(10)$ & $0.0523(4)$ & \\
\hline $\mathrm{C} 10$ & $0.47616(13)$ & $0.32563(14)$ & $0.60712(11)$ & $0.0636(5)$ & \\
\hline H10A & 0.448353 & 0.378149 & 0.618038 & $0.076^{*}$ & \\
\hline H10B & 0.521855 & 0.309673 & 0.654605 & $0.076^{*}$ & \\
\hline C11 & $0.41363(13)$ & $0.25228(15)$ & $0.58447(12)$ & $0.0689(5)$ & \\
\hline $\mathrm{C} 12$ & $0.3138(3)$ & $0.1742(3)$ & $0.6220(3)$ & $0.1086(14)$ & $0.821(8)$ \\
\hline $\mathrm{H} 12 \mathrm{~A}$ & 0.279258 & 0.167850 & 0.567335 & $0.130^{*}$ & $0.821(8)$ \\
\hline H12B & 0.346565 & 0.120368 & 0.638828 & $0.130^{*}$ & $0.821(8)$ \\
\hline $\mathrm{C} 12 \mathrm{~A}$ & $0.2830(5)$ & $0.2218(16)$ & $0.6170(13)$ & $0.112(4)$ & $0.179(8)$ \\
\hline $\mathrm{H} 12 \mathrm{C}$ & 0.247895 & 0.267217 & 0.629105 & $0.134 *$ & $0.179(8)$ \\
\hline H12D & 0.256077 & 0.199531 & 0.564315 & $0.134 *$ & $0.179(8)$ \\
\hline $\mathrm{C} 13$ & $0.2606(4)$ & $0.1904(5)$ & 0.6689 (4) & $0.145(2)$ & $0.821(8)$ \\
\hline H13A & 0.222057 & 0.141575 & 0.663721 & $0.218^{*}$ & $0.821(8)$ \\
\hline H13B & 0.295592 & 0.196529 & 0.722769 & $0.218^{*}$ & $0.821(8)$ \\
\hline $\mathrm{H} 13 \mathrm{C}$ & 0.228586 & 0.243799 & 0.651596 & $0.218^{*}$ & $0.821(8)$ \\
\hline C13A & $0.3071(18)$ & $0.1534(14)$ & $0.6746(15)$ & $0.131(6)$ & $0.179(8)$ \\
\hline H13D & 0.256994 & 0.122845 & 0.676250 & $0.197^{*}$ & $0.179(8)$ \\
\hline H13E & 0.344312 & 0.112324 & 0.661214 & $0.197 *$ & $0.179(8)$ \\
\hline
\end{tabular}




\begin{tabular}{|c|c|c|c|c|c|}
\hline $\mathrm{H} 13 \mathrm{~F}$ & 0.336264 & 0.178906 & 0.724946 & $0.197 *$ & $0.179(8)$ \\
\hline C14 & $0.61890(11)$ & $0.40053(12)$ & $0.37191(11)$ & $0.0545(4)$ & \\
\hline C15 & $0.67713(11)$ & $0.36176(13)$ & $0.27471(11)$ & $0.0575(4)$ & \\
\hline $\mathrm{H} 15 \mathrm{~A}$ & 0.707109 & 0.311554 & 0.262692 & $0.069 *$ & \\
\hline $\mathrm{H} 15 \mathrm{~B}$ & 0.718470 & 0.408417 & 0.295976 & $0.069 *$ & \\
\hline C16 & $0.61226(12)$ & $0.39333(12)$ & $0.20217(11)$ & $0.0582(4)$ & \\
\hline $\mathrm{C} 17$ & $0.5912(4)$ & $0.4604(7)$ & $0.0815(3)$ & $0.094(2)$ & $0.651(18)$ \\
\hline H17A & 0.541264 & 0.422697 & 0.062247 & $0.113^{*}$ & $0.651(18)$ \\
\hline H17B & 0.572714 & 0.519989 & 0.087923 & $0.113 *$ & $0.651(18)$ \\
\hline C17A & $0.5987(10)$ & $0.4317(12)$ & $0.0724(4)$ & $0.111(4)$ & $0.349(18)$ \\
\hline $\mathrm{H} 17 \mathrm{C}$ & 0.603984 & 0.376991 & 0.046247 & $0.133 *$ & $0.349(18)$ \\
\hline H17D & 0.538974 & 0.440902 & 0.066041 & $0.133^{*}$ & $0.349(18)$ \\
\hline $\mathrm{C} 18$ & $0.6387(5)$ & $0.4598(10)$ & 0.0289 (4) & $0.130(3)$ & $0.651(18)$ \\
\hline H18A & 0.603636 & 0.481446 & -0.021369 & $0.195^{*}$ & $0.651(18)$ \\
\hline H18B & 0.687974 & 0.497156 & 0.048961 & $0.195^{*}$ & $0.651(18)$ \\
\hline $\mathrm{H} 18 \mathrm{C}$ & 0.656703 & 0.400418 & 0.023432 & $0.195^{*}$ & $0.651(18)$ \\
\hline $\mathrm{C} 18 \mathrm{~A}$ & $0.6304(11)$ & $0.5040(12)$ & 0.0395 (11) & $0.125(5)$ & $0.349(18)$ \\
\hline H18D & 0.598396 & 0.508837 & -0.015243 & $0.188^{*}$ & $0.349(18)$ \\
\hline $\mathrm{H} 18 \mathrm{E}$ & 0.624789 & 0.557798 & 0.065709 & $0.188^{*}$ & $0.349(18)$ \\
\hline $\mathrm{H} 18 \mathrm{~F}$ & 0.689542 & 0.494139 & 0.045993 & $0.188^{*}$ & $0.349(18)$ \\
\hline C19 & $0.61117(11)$ & $0.24813(11)$ & $0.33022(10)$ & $0.0519(4)$ & \\
\hline $\mathrm{C} 20$ & $0.52672(12)$ & $0.22939(14)$ & $0.30965(11)$ & $0.0617(5)$ & \\
\hline $\mathrm{H} 20$ & 0.486416 & 0.274673 & 0.297629 & $0.074 *$ & \\
\hline $\mathrm{C} 21$ & $0.50194(15)$ & $0.14319(16)$ & $0.30689(13)$ & 0.0759 (6) & \\
\hline $\mathrm{H} 21$ & 0.444329 & 0.129315 & 0.294403 & $0.091^{*}$ & \\
\hline $\mathrm{C} 22$ & $0.56040(18)$ & $0.07794(15)$ & $0.32215(14)$ & $0.0821(7)$ & \\
\hline $\mathrm{H} 22$ & 0.543027 & 0.019086 & 0.319532 & $0.099 *$ & \\
\hline $\mathrm{C} 23$ & $0.64356(17)$ & $0.09746(15)$ & $0.34110(15)$ & $0.0804(6)$ & \\
\hline $\mathrm{H} 23$ & 0.683586 & 0.051977 & 0.351179 & $0.096^{*}$ & \\
\hline $\mathrm{C} 24$ & $0.66976(13)$ & 0.18267 (13) & $0.34571(12)$ & $0.0646(5)$ & \\
\hline $\mathrm{H} 24$ & 0.727594 & 0.196038 & 0.359409 & $0.078 *$ & \\
\hline
\end{tabular}

Atomic displacement parameters $\left(\AA^{2}\right)$

\begin{tabular}{lllllll}
\hline & $U^{11}$ & $U^{22}$ & $U^{33}$ & $U^{12}$ & $U^{13}$ & $U^{23}$ \\
\hline O1 & $0.0656(8)$ & $0.1041(12)$ & $0.0636(9)$ & $0.0104(8)$ & $0.0167(7)$ & $0.0190(8)$ \\
O2 & $0.0863(9)$ & $0.0559(8)$ & $0.0981(11)$ & $-0.0102(7)$ & $0.0532(9)$ & $-0.0039(7)$ \\
O3 & $0.0554(7)$ & $0.0897(10)$ & $0.0856(10)$ & $0.0103(7)$ & $0.0275(7)$ & $0.0135(8)$ \\
O4 & $0.0712(8)$ & $0.1044(12)$ & $0.0674(9)$ & $0.0048(8)$ & $0.0319(7)$ & $0.0265(8)$ \\
O5 & $0.1114(13)$ & $0.0924(12)$ & $0.0826(11)$ & $-0.0233(10)$ & $0.0414(10)$ & $-0.0174(9)$ \\
O6 & $0.0886(11)$ & $0.1127(14)$ & $0.0891(11)$ & $-0.0207(9)$ & $0.0504(9)$ & $-0.0027(9)$ \\
N1 & $0.0547(8)$ & $0.0648(9)$ & $0.0493(8)$ & $0.0017(6)$ & $0.0225(6)$ & $0.0000(6)$ \\
N2 & $0.0529(7)$ & $0.0578(8)$ & $0.0575(8)$ & $-0.0016(6)$ & $0.0303(7)$ & $-0.0010(6)$ \\
C1 & $0.0527(9)$ & $0.0646(11)$ & $0.0553(10)$ & $0.0013(8)$ & $0.0159(8)$ & $0.0006(8)$ \\
C2 & $0.0471(8)$ & $0.0679(11)$ & $0.0630(11)$ & $0.0021(8)$ & $0.0225(8)$ & $-0.0019(9)$ \\
C3 & $0.0526(9)$ & $0.0508(9)$ & $0.0580(10)$ & $-0.0032(7)$ & $0.0266(8)$ & $-0.0077(8)$ \\
C4 & $0.0548(9)$ & $0.0502(9)$ & $0.0524(9)$ & $0.0023(7)$ & $0.0235(8)$ & $-0.0030(7)$ \\
C5 & $0.0723(12)$ & $0.0695(12)$ & $0.0630(11)$ & $0.0116(9)$ & $0.0316(10)$ & $0.0067(9)$
\end{tabular}




$\begin{array}{lllllll}\text { C6 } & 0.0751(13) & 0.0879(15) & 0.0748(14) & 0.0290(11) & 0.0247(11) & 0.0173(12) \\ \text { C7 } & 0.0610(11) & 0.0917(15) & 0.0899(16) & 0.0266(11) & 0.0308(11) & 0.0116(13) \\ \text { C8 } & 0.0616(10) & 0.0757(12) & 0.0731(13) & 0.0137(9) & 0.0351(10) & 0.0045(10) \\ \text { C9 } & 0.0528(9) & 0.0532(9) & 0.0553(10) & 0.0041(7) & 0.0236(8) & -0.0056(7) \\ \text { C10 } & 0.0652(11) & 0.0798(13) & 0.0515(10) & -0.0011(9) & 0.0270(9) & -0.0004(9) \\ \text { C11 } & 0.0698(12) & 0.0798(13) & 0.0614(12) & -0.0012(10) & 0.0276(10) & 0.0072(10) \\ \text { C12 } & 0.106(3) & 0.118(3) & 0.119(3) & -0.036(2) & 0.061(2) & -0.002(3) \\ \text { C12A } & 0.104(6) & 0.121(6) & 0.119(6) & -0.018(6) & 0.048(6) & -0.003(6) \\ \text { C13 } & 0.118(4) & 0.180(5) & 0.169(4) & -0.032(3) & 0.091(3) & 0.006(4) \\ \text { C13A } & 0.125(10) & 0.128(10) & 0.143(10) & -0.021(9) & 0.047(10) & -0.008(10) \\ \text { C14 } & 0.0524(9) & 0.0545(10) & 0.0627(11) & -0.0039(7) & 0.0273(8) & -0.0025(8) \\ \text { C15 } & 0.0525(9) & 0.0673(11) & 0.0622(11) & -0.0001(8) & 0.0318(8) & 0.0034(8) \\ \text { C16 } & 0.0606(10) & 0.0575(10) & 0.0649(11) & 0.0047(8) & 0.0322(9) & 0.0035(8) \\ \text { C17 } & 0.092(3) & 0.129(5) & 0.068(2) & 0.034(3) & 0.035(2) & 0.039(3) \\ \text { C17A } & 0.084(5) & 0.137(8) & 0.107(6) & 0.019(6) & 0.027(5) & 0.048(5) \\ \text { C18 } & 0.140(4) & 0.196(8) & 0.059(3) & 0.047(5) & 0.040(3) & 0.028(4) \\ \text { C18A } & 0.120(8) & 0.127(8) & 0.115(8) & -0.022(7) & 0.021(6) & 0.048(7) \\ \text { C19 } & 0.0596(9) & 0.0555(9) & 0.0475(9) & -0.0043(7) & 0.0272(8) & -0.0046(7) \\ \text { C20 } & 0.0585(10) & 0.0710(11) & 0.0606(11) & -0.0066(9) & 0.0262(9) & -0.0038(9) \\ \text { C21 } & 0.0758(13) & 0.0865(15) & 0.0706(13) & -0.0277(11) & 0.0313(11) & -0.0120(11) \\ \text { C22 } & 0.1129(19) & 0.0618(12) & 0.0811(15) & -0.0200(12) & 0.0448(14) & -0.0102(11) \\ \text { C23 } & 0.0962(16) & 0.0603(12) & 0.0931(17) & 0.0033(11) & 0.0428(14) & -0.0023(11) \\ \text { C24 } & 0.0671(11) & 0.0632(11) & 0.0704(12) & 0.0029(9) & 0.0318(10) & -0.0031(9) \\ & & & & & & \end{array}$

Geometric parameters (A, $\stackrel{\circ}{)}$

\begin{tabular}{|c|c|c|c|}
\hline $\mathrm{O} 1-\mathrm{C} 1$ & $1.226(2)$ & $\mathrm{C} 12-\mathrm{C} 13$ & $1.462(5)$ \\
\hline $\mathrm{O} 2-\mathrm{C} 14$ & $1.225(2)$ & $\mathrm{C} 12 \mathrm{~A}-\mathrm{H} 12 \mathrm{C}$ & 0.9900 \\
\hline $\mathrm{O} 3-\mathrm{C} 16$ & $1.199(2)$ & $\mathrm{C} 12 \mathrm{~A}-\mathrm{H} 12 \mathrm{D}$ & 0.9900 \\
\hline $\mathrm{O} 4-\mathrm{C} 16$ & $1.324(2)$ & $\mathrm{C} 12 \mathrm{~A}-\mathrm{C} 13 \mathrm{~A}$ & $1.456(6)$ \\
\hline $\mathrm{O} 4-\mathrm{C} 17$ & $1.487(4)$ & $\mathrm{C} 13-\mathrm{H} 13 \mathrm{~A}$ & 0.9800 \\
\hline $\mathrm{O} 4-\mathrm{C} 17 \mathrm{~A}$ & $1.491(5)$ & $\mathrm{C} 13-\mathrm{H} 13 \mathrm{~B}$ & 0.9800 \\
\hline $\mathrm{O} 5-\mathrm{C} 11$ & $1.193(3)$ & $\mathrm{C} 13-\mathrm{H} 13 \mathrm{C}$ & 0.9800 \\
\hline $\mathrm{O} 6-\mathrm{C} 11$ & $1.317(2)$ & $\mathrm{C} 13 \mathrm{~A}-\mathrm{H} 13 \mathrm{D}$ & 0.9800 \\
\hline $\mathrm{O} 6-\mathrm{C} 12$ & $1.476(4)$ & $\mathrm{C} 13 \mathrm{~A}-\mathrm{H} 13 \mathrm{E}$ & 0.9800 \\
\hline $\mathrm{O} 6-\mathrm{C} 12 \mathrm{~A}$ & $1.475(6)$ & $\mathrm{C} 13 \mathrm{~A}-\mathrm{H} 13 \mathrm{~F}$ & 0.9800 \\
\hline $\mathrm{N} 1-\mathrm{C} 1$ & $1.381(2)$ & $\mathrm{C} 15-\mathrm{H} 15 \mathrm{~A}$ & 0.9900 \\
\hline $\mathrm{N} 1-\mathrm{C} 9$ & $1.390(2)$ & $\mathrm{C} 15-\mathrm{H} 15 \mathrm{~B}$ & 0.9900 \\
\hline $\mathrm{N} 1-\mathrm{C} 10$ & $1.457(2)$ & $\mathrm{C} 15-\mathrm{C} 16$ & $1.505(3)$ \\
\hline $\mathrm{N} 2-\mathrm{C} 14$ & $1.349(2)$ & $\mathrm{C} 17-\mathrm{H} 17 \mathrm{~A}$ & 0.9900 \\
\hline $\mathrm{N} 2-\mathrm{C} 15$ & $1.455(2)$ & $\mathrm{C} 17-\mathrm{H} 17 \mathrm{~B}$ & 0.9900 \\
\hline $\mathrm{N} 2-\mathrm{C} 19$ & $1.437(2)$ & $\mathrm{C} 17-\mathrm{C} 18$ & $1.453(5)$ \\
\hline $\mathrm{C} 1-\mathrm{C} 2$ & $1.451(3)$ & $\mathrm{C} 17 \mathrm{~A}-\mathrm{H} 17 \mathrm{C}$ & 0.9900 \\
\hline $\mathrm{C} 2-\mathrm{H} 2$ & 0.9500 & C17A-H17D & 0.9900 \\
\hline $\mathrm{C} 2-\mathrm{C} 3$ & $1.338(3)$ & $\mathrm{C} 17 \mathrm{~A}-\mathrm{C} 18 \mathrm{~A}$ & $1.454(6)$ \\
\hline $\mathrm{C} 3-\mathrm{C} 4$ & $1.442(2)$ & $\mathrm{C} 18-\mathrm{H} 18 \mathrm{~A}$ & 0.9800 \\
\hline $\mathrm{C} 3-\mathrm{C} 14$ & $1.510(2)$ & $\mathrm{C} 18-\mathrm{H} 18 \mathrm{~B}$ & 0.9800 \\
\hline $\mathrm{C} 4-\mathrm{C} 5$ & $1.399(3)$ & $\mathrm{C} 18-\mathrm{H} 18 \mathrm{C}$ & 0.9800 \\
\hline
\end{tabular}




\begin{tabular}{|c|c|c|c|}
\hline $\mathrm{C} 4-\mathrm{C} 9$ & $1.408(2)$ & $\mathrm{C} 18 \mathrm{~A}-\mathrm{H} 18 \mathrm{D}$ & 0.9800 \\
\hline $\mathrm{C} 5-\mathrm{H} 5$ & 0.9500 & $\mathrm{C} 18 \mathrm{~A}-\mathrm{H} 18 \mathrm{E}$ & 0.9800 \\
\hline $\mathrm{C} 5-\mathrm{C} 6$ & $1.371(3)$ & $\mathrm{C} 18 \mathrm{~A}-\mathrm{H} 18 \mathrm{~F}$ & 0.9800 \\
\hline $\mathrm{C} 6-\mathrm{H} 6$ & 0.9500 & $\mathrm{C} 19-\mathrm{C} 20$ & $1.384(2)$ \\
\hline $\mathrm{C} 6-\mathrm{C} 7$ & $1.393(3)$ & $\mathrm{C} 19-\mathrm{C} 24$ & $1.378(3)$ \\
\hline $\mathrm{C} 7-\mathrm{H} 7$ & 0.9500 & $\mathrm{C} 20-\mathrm{H} 20$ & 0.9500 \\
\hline $\mathrm{C} 7-\mathrm{C} 8$ & $1.360(3)$ & $\mathrm{C} 20-\mathrm{C} 21$ & $1.389(3)$ \\
\hline $\mathrm{C} 8-\mathrm{H} 8$ & 0.9500 & $\mathrm{C} 21-\mathrm{H} 21$ & 0.9500 \\
\hline $\mathrm{C} 8-\mathrm{C} 9$ & $1.401(2)$ & $\mathrm{C} 21-\mathrm{C} 22$ & $1.374(4)$ \\
\hline $\mathrm{C} 10-\mathrm{H} 10 \mathrm{~A}$ & 0.9900 & $\mathrm{C} 22-\mathrm{H} 22$ & 0.9500 \\
\hline $\mathrm{C} 10-\mathrm{H} 10 \mathrm{~B}$ & 0.9900 & $\mathrm{C} 22-\mathrm{C} 23$ & $1.368(4)$ \\
\hline $\mathrm{C} 10-\mathrm{C} 11$ & $1.511(3)$ & $\mathrm{C} 23-\mathrm{H} 23$ & 0.9500 \\
\hline $\mathrm{C} 12-\mathrm{H} 12 \mathrm{~A}$ & 0.9900 & $\mathrm{C} 23-\mathrm{C} 24$ & $1.380(3)$ \\
\hline $\mathrm{C} 12-\mathrm{H} 12 \mathrm{~B}$ & 0.9900 & $\mathrm{C} 24-\mathrm{H} 24$ & 0.9500 \\
\hline $\mathrm{C} 16-\mathrm{O} 4-\mathrm{C} 17$ & $115.0(3)$ & $\mathrm{H} 13 \mathrm{~A}-\mathrm{C} 13-\mathrm{H} 13 \mathrm{C}$ & 109.5 \\
\hline $\mathrm{C} 16-\mathrm{O} 4-\mathrm{C} 17 \mathrm{~A}$ & $117.2(6)$ & $\mathrm{H} 13 \mathrm{~B}-\mathrm{C} 13-\mathrm{H} 13 \mathrm{C}$ & 109.5 \\
\hline $\mathrm{C} 11-\mathrm{O} 6-\mathrm{C} 12$ & $115.0(2)$ & $\mathrm{C} 12 \mathrm{~A}-\mathrm{C} 13 \mathrm{~A}-\mathrm{H} 13 \mathrm{D}$ & 109.5 \\
\hline $\mathrm{C} 11-\mathrm{O} 6-\mathrm{C} 12 \mathrm{~A}$ & $129.0(10)$ & $\mathrm{C} 12 \mathrm{~A}-\mathrm{C} 13 \mathrm{~A}-\mathrm{H} 13 \mathrm{E}$ & 109.5 \\
\hline $\mathrm{C} 1-\mathrm{N} 1-\mathrm{C} 9$ & $123.54(14)$ & $\mathrm{C} 12 \mathrm{~A}-\mathrm{C} 13 \mathrm{~A}-\mathrm{H} 13 \mathrm{~F}$ & 109.5 \\
\hline $\mathrm{C} 1-\mathrm{N} 1-\mathrm{C} 10$ & $116.70(15)$ & $\mathrm{H} 13 \mathrm{D}-\mathrm{C} 13 \mathrm{~A}-\mathrm{H} 13 \mathrm{E}$ & 109.5 \\
\hline $\mathrm{C} 9-\mathrm{N} 1-\mathrm{C} 10$ & $119.72(15)$ & $\mathrm{H} 13 \mathrm{D}-\mathrm{C} 13 \mathrm{~A}-\mathrm{H} 13 \mathrm{~F}$ & 109.5 \\
\hline $\mathrm{C} 14-\mathrm{N} 2-\mathrm{C} 15$ & $116.96(15)$ & $\mathrm{H} 13 \mathrm{E}-\mathrm{C} 13 \mathrm{~A}-\mathrm{H} 13 \mathrm{~F}$ & 109.5 \\
\hline $\mathrm{C} 14-\mathrm{N} 2-\mathrm{C} 19$ & $124.11(13)$ & $\mathrm{O} 2-\mathrm{C} 14-\mathrm{N} 2$ & $122.43(16)$ \\
\hline $\mathrm{C} 19-\mathrm{N} 2-\mathrm{C} 15$ & $117.61(14)$ & $\mathrm{O} 2-\mathrm{C} 14-\mathrm{C} 3$ & $119.32(16)$ \\
\hline $\mathrm{O} 1-\mathrm{C} 1-\mathrm{N} 1$ & $121.49(17)$ & $\mathrm{N} 2-\mathrm{C} 14-\mathrm{C} 3$ & $118.21(15)$ \\
\hline $\mathrm{O} 1-\mathrm{C} 1-\mathrm{C} 2$ & $123.02(17)$ & $\mathrm{N} 2-\mathrm{C} 15-\mathrm{H} 15 \mathrm{~A}$ & 109.3 \\
\hline $\mathrm{N} 1-\mathrm{C} 1-\mathrm{C} 2$ & $115.48(16)$ & $\mathrm{N} 2-\mathrm{C} 15-\mathrm{H} 15 \mathrm{~B}$ & 109.3 \\
\hline $\mathrm{C} 1-\mathrm{C} 2-\mathrm{H} 2$ & 118.5 & $\mathrm{~N} 2-\mathrm{C} 15-\mathrm{C} 16$ & $111.42(14)$ \\
\hline $\mathrm{C} 3-\mathrm{C} 2-\mathrm{C} 1$ & $122.92(15)$ & $\mathrm{H} 15 \mathrm{~A}-\mathrm{C} 15-\mathrm{H} 15 \mathrm{~B}$ & 108.0 \\
\hline $\mathrm{C} 3-\mathrm{C} 2-\mathrm{H} 2$ & 118.5 & $\mathrm{C} 16-\mathrm{C} 15-\mathrm{H} 15 \mathrm{~A}$ & 109.3 \\
\hline $\mathrm{C} 2-\mathrm{C} 3-\mathrm{C} 4$ & $120.27(15)$ & $\mathrm{C} 16-\mathrm{C} 15-\mathrm{H} 15 \mathrm{~B}$ & 109.3 \\
\hline $\mathrm{C} 2-\mathrm{C} 3-\mathrm{C} 14$ & $121.19(15)$ & $\mathrm{O} 3-\mathrm{C} 16-\mathrm{O} 4$ & $125.22(19)$ \\
\hline $\mathrm{C} 4-\mathrm{C} 3-\mathrm{C} 14$ & $118.37(16)$ & $\mathrm{O} 3-\mathrm{C} 16-\mathrm{C} 15$ & $124.77(17)$ \\
\hline $\mathrm{C} 5-\mathrm{C} 4-\mathrm{C} 3$ & $122.42(16)$ & $\mathrm{O} 4-\mathrm{C} 16-\mathrm{C} 15$ & $110.01(15)$ \\
\hline $\mathrm{C} 5-\mathrm{C} 4-\mathrm{C} 9$ & $119.62(16)$ & $\mathrm{O} 4-\mathrm{C} 17-\mathrm{H} 17 \mathrm{~A}$ & 110.6 \\
\hline $\mathrm{C} 9-\mathrm{C} 4-\mathrm{C} 3$ & $117.95(16)$ & $\mathrm{O} 4-\mathrm{C} 17-\mathrm{H} 17 \mathrm{~B}$ & 110.6 \\
\hline $\mathrm{C} 4-\mathrm{C} 5-\mathrm{H} 5$ & 119.6 & $\mathrm{H} 17 \mathrm{~A}-\mathrm{C} 17-\mathrm{H} 17 \mathrm{~B}$ & 108.8 \\
\hline $\mathrm{C} 6-\mathrm{C} 5-\mathrm{C} 4$ & $120.84(18)$ & $\mathrm{C} 18-\mathrm{C} 17-\mathrm{O} 4$ & $105.6(5)$ \\
\hline $\mathrm{C} 6-\mathrm{C} 5-\mathrm{H} 5$ & 119.6 & $\mathrm{C} 18-\mathrm{C} 17-\mathrm{H} 17 \mathrm{~A}$ & 110.6 \\
\hline $\mathrm{C} 5-\mathrm{C} 6-\mathrm{H} 6$ & 120.5 & $\mathrm{C} 18-\mathrm{C} 17-\mathrm{H} 17 \mathrm{~B}$ & 110.6 \\
\hline $\mathrm{C} 5-\mathrm{C} 6-\mathrm{C} 7$ & $119.1(2)$ & $\mathrm{O} 4-\mathrm{C} 17 \mathrm{~A}-\mathrm{H} 17 \mathrm{C}$ & 110.2 \\
\hline $\mathrm{C} 7-\mathrm{C} 6-\mathrm{H} 6$ & 120.5 & $\mathrm{O} 4-\mathrm{C} 17 \mathrm{~A}-\mathrm{H} 17 \mathrm{D}$ & 110.2 \\
\hline $\mathrm{C} 6-\mathrm{C} 7-\mathrm{H} 7$ & 119.3 & $\mathrm{H} 17 \mathrm{C}-\mathrm{C} 17 \mathrm{~A}-\mathrm{H} 17 \mathrm{D}$ & 108.5 \\
\hline $\mathrm{C} 8-\mathrm{C} 7-\mathrm{C} 6$ & $121.38(18)$ & $\mathrm{C} 18 \mathrm{~A}-\mathrm{C} 17 \mathrm{~A}-\mathrm{O} 4$ & $107.6(10)$ \\
\hline $\mathrm{C} 8-\mathrm{C} 7-\mathrm{H} 7$ & 119.3 & $\mathrm{C} 18 \mathrm{~A}-\mathrm{C} 17 \mathrm{~A}-\mathrm{H} 17 \mathrm{C}$ & 110.2 \\
\hline $\mathrm{C} 7-\mathrm{C} 8-\mathrm{H} 8$ & 119.7 & $\mathrm{C} 18 \mathrm{~A}-\mathrm{C} 17 \mathrm{~A}-\mathrm{H} 17 \mathrm{D}$ & 110.2 \\
\hline $\mathrm{C} 7-\mathrm{C} 8-\mathrm{C} 9$ & $120.59(18)$ & $\mathrm{C} 17-\mathrm{C} 18-\mathrm{H} 18 \mathrm{~A}$ & 109.5 \\
\hline
\end{tabular}




\begin{tabular}{|c|c|c|c|}
\hline $\mathrm{C} 9-\mathrm{C} 8-\mathrm{H} 8$ & 119.7 & $\mathrm{C} 17-\mathrm{C} 18-\mathrm{H} 18 \mathrm{~B}$ & 109.5 \\
\hline $\mathrm{N} 1-\mathrm{C} 9-\mathrm{C} 4$ & $119.83(15)$ & $\mathrm{C} 17-\mathrm{C} 18-\mathrm{H} 18 \mathrm{C}$ & 109.5 \\
\hline $\mathrm{N} 1-\mathrm{C} 9-\mathrm{C} 8$ & $121.67(16)$ & $\mathrm{H} 18 \mathrm{~A}-\mathrm{C} 18-\mathrm{H} 18 \mathrm{~B}$ & 109.5 \\
\hline $\mathrm{C} 8-\mathrm{C} 9-\mathrm{C} 4$ & $118.50(17)$ & $\mathrm{H} 18 \mathrm{~A}-\mathrm{C} 18-\mathrm{H} 18 \mathrm{C}$ & 109.5 \\
\hline $\mathrm{N} 1-\mathrm{C} 10-\mathrm{H} 10 \mathrm{~A}$ & 109.3 & $\mathrm{H} 18 \mathrm{~B}-\mathrm{C} 18-\mathrm{H} 18 \mathrm{C}$ & 109.5 \\
\hline $\mathrm{N} 1-\mathrm{C} 10-\mathrm{H} 10 \mathrm{~B}$ & 109.3 & $\mathrm{C} 17 \mathrm{~A}-\mathrm{C} 18 \mathrm{~A}-\mathrm{H} 18 \mathrm{D}$ & 109.5 \\
\hline $\mathrm{N} 1-\mathrm{C} 10-\mathrm{C} 11$ & $111.49(16)$ & $\mathrm{C} 17 \mathrm{~A}-\mathrm{C} 18 \mathrm{~A}-\mathrm{H} 18 \mathrm{E}$ & 109.5 \\
\hline $\mathrm{H} 10 \mathrm{~A}-\mathrm{C} 10-\mathrm{H} 10 \mathrm{~B}$ & 108.0 & $\mathrm{C} 17 \mathrm{~A}-\mathrm{C} 18 \mathrm{~A}-\mathrm{H} 18 \mathrm{~F}$ & 109.5 \\
\hline $\mathrm{C} 11-\mathrm{C} 10-\mathrm{H} 10 \mathrm{~A}$ & 109.3 & $\mathrm{H} 18 \mathrm{D}-\mathrm{C} 18 \mathrm{~A}-\mathrm{H} 18 \mathrm{E}$ & 109.5 \\
\hline $\mathrm{C} 11-\mathrm{C} 10-\mathrm{H} 10 \mathrm{~B}$ & 109.3 & $\mathrm{H} 18 \mathrm{D}-\mathrm{C} 18 \mathrm{~A}-\mathrm{H} 18 \mathrm{~F}$ & 109.5 \\
\hline $\mathrm{O} 5-\mathrm{C} 11-\mathrm{O} 6$ & $125.2(2)$ & $\mathrm{H} 18 \mathrm{E}-\mathrm{C} 18 \mathrm{~A}-\mathrm{H} 18 \mathrm{~F}$ & 109.5 \\
\hline $\mathrm{O} 5-\mathrm{C} 11-\mathrm{C} 10$ & $125.32(19)$ & $\mathrm{C} 20-\mathrm{C} 19-\mathrm{N} 2$ & $120.64(16)$ \\
\hline $\mathrm{O} 6-\mathrm{C} 11-\mathrm{C} 10$ & $109.49(19)$ & $\mathrm{C} 24-\mathrm{C} 19-\mathrm{N} 2$ & $118.43(16)$ \\
\hline $\mathrm{O} 6-\mathrm{C} 12-\mathrm{H} 12 \mathrm{~A}$ & 110.3 & $\mathrm{C} 24-\mathrm{C} 19-\mathrm{C} 20$ & $120.85(18)$ \\
\hline $\mathrm{O} 6-\mathrm{C} 12-\mathrm{H} 12 \mathrm{~B}$ & 110.3 & $\mathrm{C} 19-\mathrm{C} 20-\mathrm{H} 20$ & 120.6 \\
\hline $\mathrm{H} 12 \mathrm{~A}-\mathrm{C} 12-\mathrm{H} 12 \mathrm{~B}$ & 108.6 & $\mathrm{C} 19-\mathrm{C} 20-\mathrm{C} 21$ & $118.8(2)$ \\
\hline $\mathrm{C} 13-\mathrm{C} 12-\mathrm{O} 6$ & $107.0(4)$ & $\mathrm{C} 21-\mathrm{C} 20-\mathrm{H} 20$ & 120.6 \\
\hline $\mathrm{C} 13-\mathrm{C} 12-\mathrm{H} 12 \mathrm{~A}$ & 110.3 & $\mathrm{C} 20-\mathrm{C} 21-\mathrm{H} 21$ & 119.9 \\
\hline $\mathrm{C} 13-\mathrm{C} 12-\mathrm{H} 12 \mathrm{~B}$ & 110.3 & $\mathrm{C} 22-\mathrm{C} 21-\mathrm{C} 20$ & $120.3(2)$ \\
\hline $\mathrm{O} 6-\mathrm{C} 12 \mathrm{~A}-\mathrm{H} 12 \mathrm{C}$ & 113.1 & $\mathrm{C} 22-\mathrm{C} 21-\mathrm{H} 21$ & 119.9 \\
\hline $\mathrm{O} 6-\mathrm{C} 12 \mathrm{~A}-\mathrm{H} 12 \mathrm{D}$ & 113.1 & $\mathrm{C} 21-\mathrm{C} 22-\mathrm{H} 22$ & 119.9 \\
\hline $\mathrm{H} 12 \mathrm{C}-\mathrm{C} 12 \mathrm{~A}-\mathrm{H} 12 \mathrm{D}$ & 110.5 & $\mathrm{C} 23-\mathrm{C} 22-\mathrm{C} 21$ & $120.2(2)$ \\
\hline $\mathrm{C} 13 \mathrm{~A}-\mathrm{C} 12 \mathrm{~A}-\mathrm{O} 6$ & $92.9(14)$ & $\mathrm{C} 23-\mathrm{C} 22-\mathrm{H} 22$ & 119.9 \\
\hline $\mathrm{C} 13 \mathrm{~A}-\mathrm{C} 12 \mathrm{~A}-\mathrm{H} 12 \mathrm{C}$ & 113.1 & $\mathrm{C} 22-\mathrm{C} 23-\mathrm{H} 23$ & 119.7 \\
\hline $\mathrm{C} 13 \mathrm{~A}-\mathrm{C} 12 \mathrm{~A}-\mathrm{H} 12 \mathrm{D}$ & 113.1 & $\mathrm{C} 22-\mathrm{C} 23-\mathrm{C} 24$ & $120.5(2)$ \\
\hline $\mathrm{C} 12-\mathrm{C} 13-\mathrm{H} 13 \mathrm{~A}$ & 109.5 & $\mathrm{C} 24-\mathrm{C} 23-\mathrm{H} 23$ & 119.7 \\
\hline $\mathrm{C} 12-\mathrm{C} 13-\mathrm{H} 13 \mathrm{~B}$ & 109.5 & $\mathrm{C} 19-\mathrm{C} 24-\mathrm{C} 23$ & $119.3(2)$ \\
\hline $\mathrm{C} 12-\mathrm{C} 13-\mathrm{H} 13 \mathrm{C}$ & 109.5 & $\mathrm{C} 19-\mathrm{C} 24-\mathrm{H} 24$ & 120.4 \\
\hline $\mathrm{H} 13 \mathrm{~A}-\mathrm{C} 13-\mathrm{H} 13 \mathrm{~B}$ & 109.5 & $\mathrm{C} 23-\mathrm{C} 24-\mathrm{H} 24$ & 120.4 \\
\hline $\mathrm{O} 1-\mathrm{C} 1-\mathrm{C} 2-\mathrm{C} 3$ & $-179.0(2)$ & $\mathrm{C} 10-\mathrm{N} 1-\mathrm{C} 1-\mathrm{C} 2$ & $178.29(16)$ \\
\hline $\mathrm{N} 1-\mathrm{C} 1-\mathrm{C} 2-\mathrm{C} 3$ & $0.5(3)$ & $\mathrm{C} 10-\mathrm{N} 1-\mathrm{C} 9-\mathrm{C} 4$ & $-179.07(16)$ \\
\hline $\mathrm{N} 1-\mathrm{C} 10-\mathrm{C} 11-\mathrm{O} 5$ & $15.0(3)$ & $\mathrm{C} 10-\mathrm{N} 1-\mathrm{C} 9-\mathrm{C} 8$ & $1.0(3)$ \\
\hline $\mathrm{N} 1-\mathrm{C} 10-\mathrm{C} 11-\mathrm{O} 6$ & $-166.24(17)$ & $\mathrm{C} 11-\mathrm{O} 6-\mathrm{C} 12-\mathrm{C} 13$ & $-169.7(5)$ \\
\hline $\mathrm{N} 2-\mathrm{C} 15-\mathrm{C} 16-\mathrm{O} 3$ & $-8.9(3)$ & $\mathrm{C} 11-\mathrm{O} 6-\mathrm{C} 12 \mathrm{~A}-\mathrm{C} 13 \mathrm{~A}$ & $120.5(16)$ \\
\hline $\mathrm{N} 2-\mathrm{C} 15-\mathrm{C} 16-\mathrm{O} 4$ & $171.66(16)$ & $\mathrm{C} 12-\mathrm{O} 6-\mathrm{C} 11-\mathrm{O} 5$ & $5.8(4)$ \\
\hline $\mathrm{N} 2-\mathrm{C} 19-\mathrm{C} 20-\mathrm{C} 21$ & $178.30(17)$ & $\mathrm{C} 12-\mathrm{O} 6-\mathrm{C} 11-\mathrm{C} 10$ & $-173.0(3)$ \\
\hline $\mathrm{N} 2-\mathrm{C} 19-\mathrm{C} 24-\mathrm{C} 23$ & $-177.10(18)$ & $\mathrm{C} 12 \mathrm{~A}-\mathrm{O} 6-\mathrm{C} 11-\mathrm{O} 5$ & $-32.5(12)$ \\
\hline $\mathrm{C} 1-\mathrm{N} 1-\mathrm{C} 9-\mathrm{C} 4$ & $-1.4(3)$ & $\mathrm{C} 12 \mathrm{~A}-\mathrm{O} 6-\mathrm{C} 11-\mathrm{C} 10$ & $148.7(12)$ \\
\hline $\mathrm{C} 1-\mathrm{N} 1-\mathrm{C} 9-\mathrm{C} 8$ & $178.65(18)$ & $\mathrm{C} 14-\mathrm{N} 2-\mathrm{C} 15-\mathrm{C} 16$ & $-79.0(2)$ \\
\hline $\mathrm{C} 1-\mathrm{N} 1-\mathrm{C} 10-\mathrm{C} 11$ & $-104.9(2)$ & $\mathrm{C} 14-\mathrm{N} 2-\mathrm{C} 19-\mathrm{C} 20$ & $54.7(3)$ \\
\hline $\mathrm{C} 1-\mathrm{C} 2-\mathrm{C} 3-\mathrm{C} 4$ & $-0.7(3)$ & $\mathrm{C} 14-\mathrm{N} 2-\mathrm{C} 19-\mathrm{C} 24$ & $-128.68(19)$ \\
\hline $\mathrm{C} 1-\mathrm{C} 2-\mathrm{C} 3-\mathrm{C} 14$ & $174.41(17)$ & $\mathrm{C} 14-\mathrm{C} 3-\mathrm{C} 4-\mathrm{C} 5$ & $6.1(3)$ \\
\hline $\mathrm{C} 2-\mathrm{C} 3-\mathrm{C} 4-\mathrm{C} 5$ & $-178.65(19)$ & $\mathrm{C} 14-\mathrm{C} 3-\mathrm{C} 4-\mathrm{C} 9$ & $-175.41(15)$ \\
\hline $\mathrm{C} 2-\mathrm{C} 3-\mathrm{C} 4-\mathrm{C} 9$ & $-0.1(3)$ & $\mathrm{C} 15-\mathrm{N} 2-\mathrm{C} 14-\mathrm{O} 2$ & $-2.0(3)$ \\
\hline $\mathrm{C} 2-\mathrm{C} 3-\mathrm{C} 14-\mathrm{O} 2$ & $-109.2(2)$ & $\mathrm{C} 15-\mathrm{N} 2-\mathrm{C} 14-\mathrm{C} 3$ & $-179.57(15)$ \\
\hline $\mathrm{C} 2-\mathrm{C} 3-\mathrm{C} 14-\mathrm{N} 2$ & $68.5(2)$ & $\mathrm{C} 15-\mathrm{N} 2-\mathrm{C} 19-\mathrm{C} 20$ & $-111.76(18)$ \\
\hline $\mathrm{C} 3-\mathrm{C} 4-\mathrm{C} 5-\mathrm{C} 6$ & $178.5(2)$ & $\mathrm{C} 15-\mathrm{N} 2-\mathrm{C} 19-\mathrm{C} 24$ & $64.9(2)$ \\
\hline
\end{tabular}




$\begin{array}{llll}\mathrm{C} 3-\mathrm{C} 4-\mathrm{C} 9-\mathrm{N} 1 & 1.2(2) & \mathrm{C} 16-\mathrm{O} 4-\mathrm{C} 17-\mathrm{C} 18 & -157.1(9) \\ \mathrm{C} 3-\mathrm{C} 4-\mathrm{C} 9-\mathrm{C} 8 & -178.90(17) & \mathrm{C} 16-\mathrm{O} 4-\mathrm{C} 17 \mathrm{~A}-\mathrm{C} 18 \mathrm{~A} & 152.2(17) \\ \mathrm{C} 4-\mathrm{C} 3-\mathrm{C} 14-\mathrm{O} 2 & 66.1(2) & \mathrm{C} 17-\mathrm{O} 4-\mathrm{C} 16-\mathrm{O} 3 & 0.6(5) \\ \mathrm{C} 4-\mathrm{C} 3-\mathrm{C} 14-\mathrm{N} 2 & -116.24(19) & \mathrm{C} 17-\mathrm{O} 4-\mathrm{C} 16-\mathrm{C} 15 & -180.0(5) \\ \mathrm{C} 4-\mathrm{C} 5-\mathrm{C} 6-\mathrm{C} 7 & 0.1(4) & \mathrm{C} 17 \mathrm{~A}-\mathrm{O} 4-\mathrm{C} 16-\mathrm{O} 3 & 1.0(10) \\ \mathrm{C} 5-\mathrm{C} 4-\mathrm{C} 9-\mathrm{N} 1 & 179.72(17) & \mathrm{C} 17 \mathrm{~A}-\mathrm{O} 4-\mathrm{C} 16-\mathrm{C} 15 & -168.50(18) \\ \mathrm{C} 5-\mathrm{C} 4-\mathrm{C} 9-\mathrm{C} 8 & -0.3(3) & \mathrm{C} 19-\mathrm{C} 14-\mathrm{O} 2 & 13.9(3) \\ \mathrm{C} 5-\mathrm{C} 6-\mathrm{C} 7-\mathrm{C} 8 & 0.2(4) & \mathrm{C} 19-\mathrm{N} 2-\mathrm{C} 15-\mathrm{C} 16 & 88.48(19) \\ \mathrm{C} 6-\mathrm{C} 7-\mathrm{C} 8-\mathrm{C} 9 & -0.5(4) & \mathrm{C} 19-\mathrm{C} 20-\mathrm{C} 21-\mathrm{C} 22 & -1.9(3) \\ \mathrm{C} 7-\mathrm{C} 8-\mathrm{C} 9-\mathrm{N} 1 & -179.5(2) & \mathrm{C} 20-\mathrm{C} 19-\mathrm{C} 24-\mathrm{C} 23 & -0.5(3) \\ \mathrm{C} 7-\mathrm{C} 8-\mathrm{C} 9-\mathrm{C} 4 & 0.6(3) & \mathrm{C} 21-\mathrm{C} 22-\mathrm{C} 23-\mathrm{C} 24 & 0.8(4) \\ \mathrm{C} 9-\mathrm{N} 1-\mathrm{C} 1-\mathrm{O} 1 & -179.89(19) & \mathrm{C} 22-\mathrm{C} 23-\mathrm{C} 24-\mathrm{C} 19 & 0.5(4) \\ \mathrm{C} 9-\mathrm{N} 1-\mathrm{C} 1-\mathrm{C} 2 & 0.6(3) & \mathrm{C} 24-\mathrm{C} 19-\mathrm{C} 20-\mathrm{C} 21 & -0.7(3) \\ \mathrm{C} 9-\mathrm{N} 1-\mathrm{C} 10-\mathrm{C} 11 & 72.9(2) & & 1.8(3) \\ \mathrm{C} 9-\mathrm{C} 4-\mathrm{C} 5-\mathrm{C} 6 & 0.0(3) & & \end{array}$

Hydrogen-bond geometry $\left(\AA,{ }^{\circ}\right)$

\begin{tabular}{lllll}
\hline$D-\mathrm{H} \cdots A$ & $D-\mathrm{H}$ & $\mathrm{H} \cdots A$ & $D \cdots A$ & $D-\mathrm{H} \cdots A$ \\
\hline $\mathrm{C} 7-\mathrm{H} 7 \cdots \mathrm{O} 2^{\mathrm{i}}$ & 0.95 & 2.46 & $3.404(2)$ & 171 \\
$\mathrm{C} 12 A-\mathrm{H} 12 D \cdots{ }^{3}{ }^{i i}$ & 0.99 & 2.73 & $3.477(14)$ & 132 \\
$\mathrm{C} 17 A-\mathrm{H} 17 C \cdots \mathrm{O} 1^{\mathrm{iii}}$ & 0.99 & 2.73 & $3.377(17)$ & 124 \\
$\mathrm{C} 22-\mathrm{H} 22 \cdots 3^{\text {iv }}$ & 0.95 & 2.42 & $3.342(3)$ & 164 \\
\hline
\end{tabular}

Symmetry codes: (i) $x-1 / 2,-y+1, z$; (ii) $-x+1 / 2, y,-z+1$; (iii) $x,-y+1 / 2, z-1 / 2$; (iv) $-x+1, y-1 / 2,-z+1 / 2$. 